\title{
Micromorphological evidence of liquefaction, injection and sediment deposition during basal sliding of glaciers
}

\author{
Emrys Phillips ${ }^{1 *}$, Ewelina Lipka² and Jaap J.M. van der Meer ${ }^{3}$ \\ 1. British Geological Survey, Murchison House, West Mains Road, Edinburgh EH9 3LA, UK \\ 2. Institute of Geoecology and Geoinformation, Department of Geomorphology, Adam Mickiewicz University, \\ Dziegielowa 27, 61-680 Poznan, Poland
}

3. School of Geography, Queen Mary, University of London, Mile End Road, London E1 4NS, UK

* Corresponding author, e-mail: erp@bgs.ac.uk

\begin{abstract}
The sliding of an ice mass over its bed represents one of the main mechanisms for the forward motion of glaciers and ice sheets, facilitated by the periodic introduction of meltwater along the ice-bed interface or regelation of the overriding ice. In the geological record, however, physical evidence of this process having occurred beneath former ice masses is apparently limited. This paper presents the results of a detailed micromorphological study of thinly stratified subglacial tills exposed at two sites: (i) Galmis in Switzerland and (ii) Plumpe Farm, near Gretna in SW Scotland. The stratification within these tills comprises alternating layers of massive to weakly foliated diamicton and variably deformed (folded, faulted) laminated silt and clay. Microtextural and microstructural evidence is interpreted in terms of repeated phases of basal sliding as the ice overrode a soft-sediment bed. Elevated meltwater contents/pressures encountered immediately prior to, and during basal sliding promoted localised liquefaction within the bed. Decoupling of the ice mass from its bed enabled the injection of the liquefied diamicton along the ice-bed interface and/or into the laminated sediments immediately adjacent to this boundary. The laminated silts and clays record the settling out of fines (clay, silt) from meltwater trapped along the ice-bed interface after an individual phase of basal sliding has ceased. Injection of till into the locally water saturated silts and clays resulted in partial liquefaction and incomplete mixing of these finegrained sediments with the diamicton. Density contrasts between the two liquefied sediments led to the development of a complex 'vinaigrette-like' texture comprising rounded to irregular till pebbles within a matrix of variably homogenised silty clay. Recoupling of the ice with its bed led to localised folding and thrusting within the laminated silts and clays, hydrofracturing and injection of a network of sand-filled veins, and the imposition of a variably developed clast microfabric in the diamicton layers. Analysis of the clast microfabrics indicates that the intensity of these fabrics is highly variable reflecting the variation in the intensity of deformation imposed by the overriding ice.
\end{abstract}

Keywords: micromorphology; basal sliding; till liquefaction and injection; soft-sediment deformation 


\section{Introduction}

The sliding of a glacier and/or ice sheet over its bed represents one of the principal mechanisms for the forward motion of both former and contemporary ice masses (Benn and Evans 2010 and references therein). The basal sliding process is facilitated by either the introduction of meltwater along the ice-bed interface and/or the liberation of meltwater in response to regelation of the ice immediately adjacent to this boundary. The temporally variable nature of these conditions is thought to result in a stick-slip style of motion with phases of basal sliding leading to the repeated decoupling of the ice from its bed (Fischer and Clark, 1997; Fischer et al., 1999; Winberry et al., 2009). This style of motion may occur over both hard (bedrock) and soft (sediment) beds. However, physical evidence in the geological record of this style of glacier motion having occurred over soft-sedimentary beds is apparently limited. Consequently, very little detail is known of the processes occurring during the sliding of ice over a soft bed.

Micromorphology is increasingly being used by glaciologists and Quaternary geologists as a primary tool for the analysis of subglacial sediments as the technique can provide far greater detail of the depositional and deformation histories recorded by these sediments than can be obtained from macro-scale studies alone (see Menzies and Maltman, 1992; van der Meer, 1997; Menzies et al., 1997; Khatwa and Tulaczyk, 2001; van der Meer et al., 2003; Roberts and Hart, 2005; Hiemstra et al., 2005; Evans et al., 2006; Baroni and Fasano, 2006; Larsen et al., 2006, 2007; Phillips et al., 2011; Neudorf et al., 2013). In particular, this approach has been used to unravel the often complex deformation histories recorded by glacigenic sequences (van der Meer, 1993; Phillips and Auton, 2000; van der Wateren et al., 2000; Menzies, 2000; Phillips et al., 2007; Lee and Phillips, 2008; Denis et al., 2010; Vaughan-Hirsch et al., 2012; Narloch et al., 2012, 2013) as well as investigate the role played by pressurised melt water during these deformation events (Hiemstra and van der Meer, 1997; Phillips and Merritt, 2008; van der Meer et al., 2009; Denis et al., 2010; Phillips et al., 2012; Narloch et al., 2012, 2013). Subglacial diamictons are typically polydeformed deposits, the so-called "tectomict" of Menzies et al. (2006), having encountered several phases of deformation during either a single progressive event associated with a single phase of ice advance, or several multiple deformation events related to separate phases/pulses of ice advance. The recent development of a quantitative microstructural mapping method (Phillips et al., 2011) has the potential to increase our understanding of the processes occurring during subglacial deformation by highlighting the relationships between the various microstructures developed within the sediment thereby allowing a detailed relative chronology of deformation events to be established.

This paper presents the results of a detailed microstructural and sedimentological study of thinly stratified subglacial tills exposed at Galmis, Switzerland and Plumpe Farm, near Gretna in SW Scotland. The complex relationships displayed between the variably deformed, finely laminated silts and clays, and diamicton layers which comprise these stratified tills are interpreted in terms of a basal sliding model. The micromorphology of these sediments yields valuable insights into the processes occurring during basal sliding which include soft-sediment deformation, till liquefaction and injection, as well as the 
penecontemporaneous deposition of fines due to ponding of meltwater between individual "sliding events". Quantitative data (E1 and E2 eigenvalues) obtained for clast microfabrics present within the diamicton layers are used to investigate the variation in the intensity and partitioning of deformation imposed by the overriding ice as it recouples with the bed. The potential triggers leading to liquefaction of the diamicton within the soft-sediment bed during basal sliding are also discussed.

\section{Location of study areas and methodology}

The thin sections of thinly stratified till examined during this study were collected from the glacigenic sequences exposed at two sites: (i) a complex sequence of both massive and stratified subglacial diamictons revealed in a large gravel pit near Galmis (Latitude $46^{\circ} 51^{\prime}$ $44.08^{\prime \prime} \mathrm{N}$; longitude $7^{\circ} 12^{\prime} 56.80^{\prime \prime} \mathrm{E}$ ) in the western part of the Swiss Plateau, to the east of Lake Schiffenen and northeast of Fribourg (van der Meer, 1979, 1982); and (ii) from the stratified base of a massive diamicton overlying a sequence of laminated glaciofluvial/glaciolacustrine sands, silts and gravels exposed behind farm buildings at Plumpe Farm (UK National Grid Reference NY 3344 6813) to the east of the Scottish Border at Gretna (Phillips et al., 2007). Prior to sampling the sections at both sites were logged, photographed and described in detail (Figs. 1 and 2) with particular emphasis being placed on recording the macroscale variation in lithology and structure of the tills. At Galmis seven intact block samples of the thinly stratified and associated massive diamictons (Fig. 1) were collected in the mid to late 1970's (van der Meer, 1979, 1982) using a combination of Kubiena and mammoth tins. At Plumpe Farm four samples were collected across the boundary between the glaciofluvial/glaciolacustrine deposits and overlying diamicton using $10 \mathrm{~cm}$ cubed Kubiena tins (Fig. 2). The tins were either cut (using a knife or plaster board/rock hand saw) or pushed into the face in order to limit sample disturbance. The position of the sample within the glacigenic sequence, its orientation relative to magnetic north, depth and way-up were marked on the outside of the tin during collection. The samples were collected at different stratigraphical/structural levels within the sequence to provide detailed information on the internal architecture of the tills and range of microstructures developed within these complex deposits. Each sample was then removed from the face, sealed in two plastic bags, and stored in a cold store to prevent the material drying out prior to sample preparation.

Sample preparation involves the replacement of pore-water by acetone, which is then progressively replaced by a resin and allowed to cure. Large format orientated thin sections were taken from the centre of each of the prepared samples, thus avoiding artifacts associated with sample collection. Each thin section was cut orthogonal to the stratification/bedding within the sediment and parallel to the main ice movement direction in the study area. The thin sections were examined using a standard Zeiss petrological microscope and Zeiss projector, the latter allowing detailed study of the range of microstructures at very low magnification. The terminology used to describe the various microtextures developed within these sediments in general follows that proposed by van der Meer $(1987,1993)$ and Menzies (2000) with modifications. Detailed microstructural maps (see Figs. 3 to 9 and 11 to 15) and 
quantitative data for the clast microfabrics (rose diagrams on Figs. 3 to 9 and 11 to 15) developed within the diamicton layers were obtained using the methodology of Phillips et al. (2011) (also see Vaughan-Hirsh et al., 2013; Neudorf et al., 2013). This microstructural mapping approach was used alongside existing methods of analysis resulting in the detailed microstructural and sedimentological analysis of the glacigenic sediments exposed at both sites. Plotting of the orientation data obtained for the long axes of fine sand to pebble sized clasts (skeleton grains) within the diamictons on a series rose diagrams and calculation of the eigenvalues (Fig. 10 and Table 1) were carried out using the commercial software package StereoStat by Rockware. For ease of description the results of the studies at each site are presented separately.

\section{Galmis, Switzerland}

The gravel pit at Galmis is located on the western side of an elongate drumlin (Crausaz, 1959). In the mid to late 1970's, when the samples were collected, the active quarry face was cut oblique to the long axis of the landform and was approximately $150 \mathrm{~m}$ in length and up to $12 \mathrm{~m}$ high (van der Meer, 1979). The exposed sequence comprised a lower, 5 to $6 \mathrm{~m}$ thick unit of fluvioglacial sands and gravels which grade upwards into a c. $9 \mathrm{~m}$ thick unit of variably stratified diamicton (till) (Fig. 1a). The top of the sequence comprises c. $3 \mathrm{~m}$ of sand and coarse gravel (Fig. 1a). The till at the northern-end of the section comprises three distinct units: (i) A lower weakly bedded, very hard (compact) gravelly diamicton (Fig. 1b); (ii) A c. $50 \mathrm{~cm}$ thick, laterally discontinuous unit of thinly stratified, diamicton (Figs. $1 \mathrm{~b}$ and c) composed of thin layers of diamicton separated by finely laminated silt and clay. The lamination within the silts and clays is locally deformed by small-scale, tight, moderately inclined to recumbent, asymmetrical folds (Fig. 1d); and (iii) An upper unit of bedded diamicton containing laterally impersistent and variably deformed (folded) layers of sand and laminated silt and clay. At the southern end of the section this tripartite sequence is absent with the sequence being dominated by the upper bedded diamicton containing isolated lenses of the gravelly and thinly stratified diamictons (Fig. 1a). All of the diamictons are hard and compact (overconsolidated) consistent with them having formed subglacially or having been overridden by ice. Van der Meer (1982) suggested that the stratified diamictons were formed by alternating deposition of till during coupling and deposition of rhythmites during decoupling.

\subsection{Micromorphology}

The locations of the thin sections collected from the diamictons at Galmis are shown on Fig. 1a. For ease of description the micromorphology of these diamictons are considered separately.

\subsubsection{Lower gravelly diamicton (till)}

Thin section R.166 is from the lower gravelly diamicton (Fig. 1a) and comprises a poorly sorted, clast-rich, texturally and compositionally immature pebbly sandy diamicton with an open packed, matrix-supported texture (Fig. 3). Subrounded to well-rounded, low-sphericity, coarse sand to pebble sized clasts within the diamicton are dominated by fragments of 
sandstone, siltstone and limestone. These include broken fragments of larger pebbles (see Fig. 3) indicative of a polycyclic origin for this sediment. Coarse silt to coarse sand grade clasts within the finer grained matrix to the diamicton are mainly composed of angular to subangular, mono- and polycrystalline quartz with minor feldspar and carbonate. These fine grained clasts exhibit a variably developed preferred shape alignment, defining a number of clast microfabrics (see below). Arcuate to curved grain alignments (turbate structures of van der Meer, 1993) developed immediately adjacent to the pebbles are interpreted as recording the variable rotation of the larger clasts during either compaction and/or deformation. No obvious plasmic fabrics have been identified, possibly due to the high proportion of finegrained carbonate within the matrix.

Four generations of clast microfabrics have been identified with the relative chronology of these foliations (S1 earliest, S4 latest) being established by locally developed cross-cutting relationships between the fabrics. The heterogeneously developed S1 fabric (pale purple on Fig. 3) is defined by short, discontinuous, irregular to folded domains. A second (S2), gently to moderately inclined (c. $35^{\circ}$ ), spaced foliation (dark purple on Fig. 3 ) is defined by discontinuous moderately inclined domains. S1 is preserved within pressure shadows developed adjacent to granule to pebble sized clasts and the microlithons between the S2 domains, with this second fabric taking the form of a variably developed crenulation foliation. Granule to pebble sized clasts acted as relatively rigid bodies during deformation leading to the development of pressure shadows adjacent to these clasts, allowing the preservation of earlier formed features during continued or subsequent phases of foliation development. The third fabric, S3 (green on Fig. 3), cuts across both S1 and S2, and is primarily developed within the upper part of the thin section where the spacing of the foliation appears to have been controlled by the larger pebbles (Fig. 3). A late steeply inclined to subvertical, locally well-developed, anastomosing S4 fabric (brown on Fig. 3) cuts across all of the earlier developed foliations. Imposition of the S4 within the matrix of the diamicton also led to the development of a preferred alignment of the pebble sized clasts.

\subsubsection{Stratified diamicton (till)}

Samples R.164, R.163A, B, C and D, and R.248 (Figs. 4 to 9, respectively) were all taken from the stratified till (Fig. 1a) and are composed of thin (1 to $20 \mathrm{~mm}$ thick), lenticular to laterally extensive layers of poorly sorted, sandy diamicton separated by layers of finely laminated, slightly calcareous silt and clay. The boundaries between the diamicton and adjacent fine-grained sediments are typically sharp, but vary from smooth, to lobate, through to highly irregular or involuted in form (Figs. 4, 5, 6, 7 and 8). The more complex boundaries are typically associated with the presence of rounded, lenticular, to irregular or ribbon-like till pebbles (van der Meer, 1993) included within the silt and clay (Figs. 4, 6, and 7). These complex boundaries also locally cross-cut the lamination within the silts and clays, indicating that they are not simple sedimentary/depositional contacts. The layering within the stratified till locally wraps around the larger pebbles (Figs. 4, 7 and 8) resulting in the formation of pressure shadows adjacent to these clasts which acted as rigid bodies during deformation. The asymmetry of the pressure shadows in some samples, coupled with the geometry of the layering as it distorts around these large clasts, record the variable rotation of the pebbles 
during deformation (Figs. 4 and 7). Small-scale, crenulation-style folds are locally developed immediately adjacent to these rotated clasts where they deform the lamination within the host silts and clays (Figs. 6 and 8). The symmetrical nature of the deformation adjacent to a large, well-rounded pebble in the centre of sample R.163C (Fig. 7), however, is consistent with compaction of the sediment around this rigid clast (pure shear), rather than shearing (simple shear) imposed by the overriding ice. This deformation includes box-like folding of the overlying diamicton layers (the intensity of this folding decreases upwards) and localised small-scale thrusting within the laminated silts and clays immediately below this pebble, with the thrusts showing an opposing sense of displacement on either side of the clast (Fig. 7).

The laminated silts and clays locally exhibit a well-developed normal and occasionally reverse grading, consistent with a waterlain origin for these fine-grained sediments. Isolated sand grains and small pebbles which appear to 'float' within these finegrained sediments are interpreted as dropstones. Rounded, irregular to locally lenticular (eyeshaped) 'till pebbles' also occur within the silts and clays (Fig. 6), with these 'fragments' of till increasing in number adjacent to the layers of diamicton (Figs. 5, 6 and 7). In the majority of the thin sections the laminated silts and clays are relatively undeformed with the graded silt-clay laminae recording that these fine-grained sediments are the right way-up (Figs. 4, 6, 7 and 8). Deformation, where apparent, resulted in the imposition of a locally well-developed bedding-parallel plasmic fabric within the clay-rich laminae. This plasmic fabric, along with the sedimentary lamination, is locally distorted around the dropstones consistent with the variable rotation of these skeleton grains.

In the more highly deformed samples the lamination and bedding-parallel plasmic fabric are folded (Figs. 4, 5, 6 and 8) and/or offset by small-scale faults (Fig. 5 and 9). Smallscale, asymmetrical, recumbent to isoclinal, locally rootless folds occur immediately above prominent bedding surfaces and/or slightly thicker clay lamina, and can be seen to die out laterally (see top Fig. 8). These folds possess arcuate to curved axial surfaces consistent with their formation in response to a simple shear style of deformation, possibly as a result of minor detachment and movement along bedding. Micro-scale 'quarter folds' (Passchier and Trouw, 1996; Phillips and Lee, 2011) were also noted developed upon some of the skeleton grains included within the laminated silts and clays. In sample R.163A, the lamination within a thick silt-clay layer (top of the thin section, Fig. 5) is deformed by a tight to isoclinal, recumbent fold which is itself cut by a fine, anastomosing network of clay and carbonatefilled veinlets. These veinlets also permeate the underlying silts and clays, but are absent within the intervening diamicton (see Fig. 5). Bedding on the lower limb of the fold is overturned and truncated by a 10 to $15 \mathrm{~mm}$ thick band of diamicton. The remaining layers of laminated silt and clay in sample R.163A are unaffected by this folding, indicating that deformation was highly heterogeneous and partitioned into discrete horizons within the stratified till.

The diamicton layers within the thinly stratified till are lithologically similar to the matrix of the structurally underlying gravelly diamicton with the coarser sand to pebble sized clasts being mainly composed of sedimentary rock fragments. These large clasts are locally enclosed in a partial to complete rim or coating of fine silt. The individual diamicton layers 
vary from massive to fragmentary or 'globular' in appearance comprising rounded, elongate to irregular till pebbles within a very weakly laminated to massive silt and/or silty clay matrix (Figs. 4, 6 and 7). The more massive, silty clay matrix locally possesses a mottled appearance which is typically equated with liquefaction of the sediment. The homogenised silty matrix within the diamicton is locally spatially associated with the disruption of bedding within the adjacent laminated silts and clays. In contrast to the gravelly diamicton, clast microfabrics development within the diamicton layers of the stratified till are in general less pronounced and more variable in their intensity (see Figs. 4 to 8). Three generations of clast microfabrics have been recognised. The earliest, $\mathrm{S} 1$, is a moderately to steeply inclined $\left(40^{\circ}\right.$ to $\left.60^{\circ}\right)$ foliation defined by short, crenulated (folded) domains preserved within the microlithons of a more widely spaced S2 fabric (Figs. 5 and 8). This moderately inclined ( $45^{\circ}$ to $55^{\circ}$ ) second foliation (S2) is defined by short to elongate, irregular domains which locally wrap around the larger skeletal grains. Grain stacks, linear to arcuate grain alignments and turbate structures (van der Meer, 1993) developed within the sandy matrix to the diamicton layers are preserved within the S2 microlithons. The arcuate grain alignments locally define an asymmetrical, S-C-like fabric geometry which records a sinistral sense of shear (in this plane of section; Fig. 5); comparable to the sense of rotation recorded by granule to pebble sized clasts (see Figs. 4, 6 and 8). The heterogeneously developed S3 cuts across both S1 and S2, and is the youngest fabric recognised within the diamicton layers. Orientation data obtained for these clast microfabrics and the adjacent massive tills (see sections 3.1.1 and 3.1.3, Figs. 3 to 9,11 and 12) suggests that they are coplanar and that they formed under the same overall stress regime. This also suggests that although the sequence at Galmis can be divided into three units, the thinly stratified till forms an integral part of this overconsolidated subglacial till sequence.

The intensity of foliation development varies considerably even within a single sample (see Figs. 6 and 7), with the clast microfabrics being more pronounced within the thicker diamicton layers (compare Figs. 5 and 6). This variation in fabric intensity can be illustrated qualitatively by plotting the clast long axis data for each diamicton layer within a single sample on a series of rose diagrams (e.g. see Fig. 7), and quantitatively by the variation in the calculated eigenvalues (E1 and E2) for these diamicton layers (Fig. 10 and Table 1). It is clear from Fig. 10 that there is no single overall pattern in the variation in clast microfabric intensity within the Galmis stratified till. For example, samples R.163A and R.163C exhibit an overall upward decrease in E1 eigenvalue, whereas sample R.163B lacks any obvious systematic variation in either E1 or E2 (Fig 10).

The relationships between the diamicton and silt-clay layers within sample R.248 are far more complex (Fig. 9). At the macroscale the contact between the two lithologies appears sharp, however, under the microscope it can be seen that this boundary is highly involuted with the fine-grained sediments grading into the matrix of the diamicton. Importantly this lithological boundary cuts across and locally disrupts the lamination within the adjacent finegrained sediments, indicating that relationship between the two layers is not a simple sedimentary/depositional contact. Adjacent to the contact the lamination within the silt and clay layer is either absent or has been overprinted, with the silty clay possessing a 'turbid' 
appearance. This mottled silty clay contains rounded to irregular till pebbles as well as granule to small pebble sized skeleton grains derived from the diamicton (see Fig. 9). The diamicton layer also displays a turbid to fragmented appearance comprising pale, irregular 'pebbles' of sandy diamicton within a darker silty diamicton matrix. The silty diamicton also contains thin, irregular veinlets, lenticles or ribbons of clay and silt. Shape-aligned granules to pebble sized clasts within the diamicton define a curved to weakly arcuate clast fabric (curved red arrow on Fig. 9). A weakly developed, moderately inclined (c. 45 , Fig. 9) clast microfabric present within the matrix of the diamicton occurs coplanar to the foliation defined by the larger skeleton grains. Orientation data obtained for this microfabric suggests that it occurs parallel to the thrust faults in the adjacent laminated silt and clay (see rose diagrams on Fig. 9), indicating that these microstructures may have developed as a result of the same overall stress regime. The intensity of faulting and minor recumbent folding of the laminated slit and clay increases towards the involuted boundary with the diamicton (Fig. 9), suggesting that deformation was being focused along this contact. However, these obvious deformation structures are apparently confined to the laminated silts and clays, and do not appear to have propagated into the adjacent diamicton.

\subsubsection{Upper diamicton (till)}

Samples R.165 (Fig. 11) and R.419 (Fig. 12) were collected from the diamicton forming the upper part of the till sequence at Galmis (Fig. 1). Thin section R.165 comprises a poorly sorted, texturally and compositionally immature, pebbly sandy diamicton which is lithologically similar to the diamicton layers within the underlying stratified till. Although apparently massive in appearance three generations of clast microfabrics have been identified within this diamicton: (i) an early, poorly developed/preserved S1 fabric (pale purple on Fig. 11); (ii) a more pervasively developed, heterogeneous, moderately inclined S2 fabric (dark purple on Fig. 11) defined by elongate, irregular to locally anastomosing domains; and (iii) a weakly developed, subhorizontal S3 fabric (green on Fig. 11), imposition of this foliation resulted in the deformation of the earlier S2 resulting in a weak sigmoidal to arcuate, S-C-like fabric geometry (red dashed lines of Fig. 11), indicating an apparent sinistral sense of shear in this plane of section. The intensity of S2 varies across the thin section reflecting the partitioning of deformation within the matrix of the till. The darker blue coloured areas on Fig. 11 highlight these areas of relatively more intense foliation development. No plasmic fabrics have been identified within the matrix to this diamicton possibly due to the relatively high modal proportions of carbonate within the clay- to fine-silt grade components.

The structurally higher sample R.419 (Fig. 12), although from the upper diamicton at Galmis, is lithologically similar to samples R.164, R.163A, B, C and D, and R.248 (compare Fig. 12 with Figs. 3 to 8 ) and comprises alternating layers of pebbly sandy diamicton and laminated silt and clay. Three generations of clastic microfabrics (S1 to S3) have been recognised in sample R.419, with the moderately (c. $47^{\circ}$ ) inclined, heterogeneously developed S2 fabric forming the dominant foliation (Fig. 12). Both the stratification and clast microfabrics can be seen wrapping around the larger pebbles recording a dextral sense of rotation within this plane of section. The lamination within the fine-grained sediments is offset by a number of low-angle shears and thrusts. These predominantly brittle structures 
appear coplanar to the weakly developed, subhorizontal S3 fabric present within the adjacent diamicton layers (Fig. 12).

\section{Plumpe Farm, Gretna, Scotland}

The site at Plumpe Farm occurs within the Solway Lowlands, an area of gently undulating, low-lying ground which was overridden during the Late Devensian by ice advancing southward from the Scottish Southern Uplands (Trotter, 1922; Trotter and Hollingworth, 1932; Merritt and Auton, 2000; Huddart and Glasser, 2002). The lower part of the sequence exposed at Plumpe Farm comprises laminated glaciofluvial and glaciolacustrine sediments of the Plumpe Sand and Gravel Formation (Fig. 2). These medium- to fine-grained, graded and locally ripple cross-laminated sands and silts were deposited during the initial retreat of the Southern Uplands ice. The upper part of the Plumpe Sand and Gravel Formation is very hard and compact (overconsolidated) and appears to grade into the base of the overlying diamicton (Plumpe Bridge Till, Fig. 2). The base of this matrix-supported, gravelly sandy diamicton is stratified, the latter defined by thin elongate lenses and ribbons of silty clay. This stratified base to the till passes upwards into a massive overconsolidated diamicton. This till is thought to record a later readvance of the Southern Uplands ice into the Solway area (Trotter, 1922; Trotter and Hollingworth, 1932; Merritt and Auton, 2000; Huddart and Glasser, 2002). Phillips et al. (2007) concluded that the apparent lack of macroscopic deformation within the underlying silts and sands was a result of the ice overriding water saturated sediments, leading to the formation of a water lubricated detachment at the base of the ice (basal sliding) decoupling it from the underlying soft-sediment bed.

\subsection{Micromorphology}

Four samples (N2840; N2841; N2842; N2843) were collected across the boundary between the Plumpe Sand and Gravel Formation and overlying Plumpe Bridge Till (Fig. 2) to examine in detail the processes occurring at the base of the ice as it overrode the water saturated sands and silts. For ease of description the micromorphology of the laminated glaciofluvial and glaciolacustrine sands, silts and clays, and overlying diamicton are considered separately.

\subsubsection{Laminated sand, silt and clay (Plumpe Sands and Gravel Formation)}

Samples N2840 (lowest) and N2841 were taken from the Plumpe Sand and Gravel Formation (Fig. 2). They are composed of a fine, rhythmically laminated sequence of fine-grained sand, silt and clay which shows very little evidence of deformation (Fig. 13). The sand and silt laminae are normal graded indicating that the sequence is the right-way-up. In sample N2840, however, a 10 to $15 \mathrm{~mm}$ thick zone of relatively intense thrusting and recumbent folding occurs in the lower part of the thin section (Fig. 13). The faults off-set bedding and are defined by thin clay seams which possess a unistrial plasmic fabric. The SE-directed sense of displacement recorded by these structures is consistent with the southerly directed ice advance across the area (Trotter, 1922; Trotter and Hollingworth, 1932; Merritt and Auton, 2000; Huddart and Glasser, 2002). The thicker clay laminae in both samples N2840 and N2841 possess a well-developed bedding-parallel plasmic fabric. 


\subsubsection{Thinly stratified diamicton (Plumpe Bridge Till)}

Samples N2842 (Fig. 14) and N2843 (highest) (Fig. 15) from the base of the Plumpe Bridge Till are composed of a thinly stratified, poorly sorted, sandy diamicton containing variably disrupted (deformed) lenses and layers of laminated silt and clay. Although sharp, the boundaries between the diamicton and silt-clay layers are highly irregular in form and locally deformed by open, cuspate synforms separated by narrow flame-like antiforms (Fig. 14). In the least disrupted silt and clay layers, a fine-scale lamination is contorted by small-scale disharmonic folds, recumbent rootless folds and flame structures. These ductile deformation structures are crosscut by thin veinlets of clay. Ductile deformation was accompanied by localised liquefaction and homogenization of the silt laminae, leading to further disruption within the silt-clay layers. The more disrupted layers comprise broken, angular fragments of laminated clay and rounded, irregular to elongate till pebbles within a homogenised silt or silty clay matrix (Fig. 14). The till pebbles are similar in composition to the adjacent diamicton layers. The clay-rich layers are also deformed by narrow shears marked by a distinct unistrial plasmic fabric.

The diamicton layers range from massive (Fig. 15) to fragmentary or 'globular' in appearance comprising rounded to elongate till pebbles supported within a matrix of clay (Fig. 14). This clay possesses a well-developed plasmic fabric (omnisepic) which wraps around the included till pebbles. Apart from locally being embayed against neighbouring more rigid rock fragments, the till pebbles are relatively undeformed. Rotational structures and arcuate grain alignments are common within the diamicton layers. Three generations (S1 to S3) of clast microfabric have been recognised within the diamicton layers; the relative intensity of these fabrics apparently increases upwards through the Plumpe Bridge Till (compare Figs. 14 and 15). This increase in microfabric strength is supported by the corresponding increase in E1 eigenvalue (Table 1). The earliest fabric (S1) occurs parallel to the stratification within the diamicton and is crosscut by the moderately inclined (c. $30^{\circ}$ to $45^{\circ}$ ), SE-dipping (down-ice) S2 and steeply (c. $50^{\circ}$ to $60^{\circ}$ ) NW-dipping (up-ice) S3 foliations (Figs. 14 and 15). In both samples the S3 fabric is spatially related to locally well-developed water-escape features, indicating that this foliation may have formed during the dewatering of the diamicton. In sample N2843 all three generations of clast microfabric have been recognised within a diffuse layer of banded silt and clay located within the middle of this thin section (Fig. 15). The occurrence of these clast microfabrics within this layer indicates that the imposition of these clast microfabrics post-dated the development of the stratification within the Plumpe Bridge Till (see below).

\section{Interpretation of the micromorphology}

It is clear from the above micromorphological description that there are a number of similarities between the tills exposed at Galmis (section 3) and Plumpe Farm (section 4), these include: 
- The presence of a well-developed centimeter- to millimeter-scale stratification defined by alternating lenticular to laterally extensive layers of diamicton separated by finely laminated silt and clay (Figs, 4, 6, 7 and 14);

- Sedimentary structures preserved within the layers of laminated silt and clay are consistent with a waterlain origin for these fine-grained sediments (Figs. 5, 6 and 8));

- The overall texture of the diamicton layers varies from massive to fragmentary or 'globular' in appearance comprising rounded, elongate to irregular till pebbles within a matrix of massive to laminated slit or silty clay (Figs. 6, 7, 8, 9, 14 and 15);

- The boundaries between the individual diamicton layers and adjacent fine-grained sediments are highly variable, even within a single thin section, and range from smooth, to lobate, through to highly irregular or involuted in form (Figs. 7, 9 and 14). These complex boundaries locally crosscut the lamination within the silts and clays, indicating that they do not represent simple sedimentary/depositional contacts;

- The intensity of deformation within the thinly stratified tills is highly variable and, where present, has been preferentially partitioned into the laminated silts and clays where it resulted in folding and thrusting, as well as normal and reverse faulting (Figs. $5,7,8,9,12$ and 14). Deformation of these fine-grained sediments is locally accompanied by liquefaction and homogenisation of the silt and fragmentation of the clay laminae;

- In the diamicton layers deformation led to the imposition of a number of relatively weakly developed clast microfabrics as well as the variable rotation of granule to pebble sized clasts and development of pressure shadows adjacent to these rigid bodies (Fig. 4 and 7);

- The diamicton layers locally crosscut and, therefore, post-date the folds and faults developed within the adjacent laminated silts and clays (Figs. 5 and 12).

- Orientation data obtained for the clast microfabrics present in the stratified and massive tills exposed at Galmis (Figs. 3 to 9, 11 and 12) suggests that they are coplanar and formed under the same overall stress regime. A similar relationship occurs within the till at Plumpe Farm (Figs. 14 and 15). Although the till sequence at Galmis is divided into three units, the thinly stratified till forms an integral part of this overconsolidated, subglacial tripartite sequence.

The range of microstructures developed in both the Galmis and Plumpe Farm tills are illustrated in Figs. 16 and 17, respectively. On these figures the microstructural maps of each of the thin sections have been placed in their approximate structural/stratigraphical order, so as to highlight any systematic variation in lithology and/or deformation at a microscale.

\subsection{Formation of a fine-scale stratification within subglacial diamictons}

Although the sedimentary structures preserved within the silt and clay layers in both tills are consistent with a waterlain origin for these fine-grained sediments, the highly complex nature of the boundaries between these laminated sediments and adjacent diamicton layers, coupled with the locally 'globular' appearance of some the bands of diamicton, are thought to be inconsistent with the thinly stratified tills representing a simple sedimentary sequence; for instance, glaciolacustrine silts and clays interbedded with very thin (distal) mass flow 
deposits. The diamicton layers can be seen to crosscut the lamination and deformation structures present within the silts and clays, indicating that their formation coincided with, or post-dated folding and thrusting. However, orientation data obtained for the clast microfabrics within the diamicton layers and thrusts and related brittle faults within the laminated silts and clays in the Galmis tills (see Figs. 9 and 12) are coplanar, leading to the conclusion that faulting and foliation development were penecontemporaneous and a result of the same overall stress regime. The overconsolidated nature of the diamicton sequences at both Galmis and Plumpe Farm suggests that this deformation was subglacial in origin. Consequently, the most likely explanation is that the fine-scale stratification within the Galmis and Plumpe Farm tills is that it formed/developed in a subglacial environment.

One of the distinctive features of the diamicton layers in both tills is that they are locally composed of rounded to irregular till pebbles within a silty clay matrix (Figs. 6, 7, 8, 9, 14 and 15). Microtextural evidence (see section 3 and 4) clearly indicates that these till pebble-rich layers formed during till deposition. Van der Meer (1993) concluded that till pebbles develop in response to rotational movement (simple shear) during subglacial deformation (also see van der Meer, 1994; Hiemstra and van der Meer, 1997). The model proposed by van der Meer (1993) requires initial fracturing of the till followed by rotation and rounding of the pebbles (see fig. 6 of Hiemstra and van der Meer, 1997); thereby imply that the sediment is relatively 'dry' to allow brittle deformation to take place. Microtextures in both the Galmis and Plumpe Farm tills, however, indicate that these thinly stratified deposits may have been water-saturated at the time of till pebble formation. For example, in the Plumpe Farm sample N2842 the till pebble-rich layers possess an open, matrix-supported texture with the matrix composed of clay (Fig. 14). In the Galmis stratified till the matrix to the pebble-rich horizons is composed of a massive (homogenised) or weakly laminated silt or silty clay (Figs. 6 and 7). Homogenisation of the silty matrix is most likely to have occurred as a result of liquefaction of the silt laminae (cf. Phillips et al., 2007), which appears to have accompanied subglacial deformation and led to the disruption of bedding within the laminated silts and clays.

Phillips et al. (2007) concluded that that distinctive 'globular' appearance of the till pebble layers within the basal zone of the Plumpe Farm stratified till (Fig. 17) formed as a result of 'partial mixing' of the water-saturated silts and clays with the diamicton during the till deposition. These authors suggested that mixing occurred in response to turbulent flow within the water-lubricated zone between the till and underlying glaciofluvial/glaciolacustrine deposits as the ice overrode and incorporated the laminated fine-grained sediments from this pre-existing sedimentary sequence (see Fig. 2). This mode of formation is also broadly applicable to the thinly stratified till exposed at Galmis. However, the thinly stratified diamictons at this site occur entirely within a thick sequence of diamictons (see Fig. 1), therefore lacking a direct source of pre-existing fine-grained sediment. The crosscutting relationships displayed between the diamicton layers and deformed silts and clays within the stratified till at Galmis and Plumpe Farm has led to the conclusion that the fine-scale layering within these subglacial tills developed in response to the injection of the liquefied (dilated) diamicton into the laminated sediments (Fig. 16). Micromorphological evidence clearly 
indicates that injection of the diamicton largely occurred parallel to bedding within the host silts and clays. The dilation of water-saturated subglacial sediments is thought to facilitate ductile bed deformation (e.g. Murray and Dowdeswell, 1992; van der Meer et al., 2003; Evans et al., 2006; Phillips et al., 2011; Menzies 2012; Neudorf et al., 2013), with this process leading to the weakening of the till by lowering the effective normal stress (i.e. the difference between ice overburden pressure and porewater pressure; Piotrowski et al., 2004; Menzies and Ellwanger, 2010). Evans et al. (2006), Denis et al. (2010) and Phillips et al. (2011) have all suggested that localised liquefaction of subglacial sediments within the active deforming layer can lead to the overprinting of preexisting structures and homogenisation of these deposits.

The liquefied diamicton at the time of injection within the Galmis and Plumpe Farm stratified tills can be considered to be a "multiphase fluid" comprising solid skeleton grains (pebbles, granules, sand grains) within a highly dilated matrix of finer grained material (silt, clay) mixed with pressurised intergranular porewater. The physical properties of the liquefied diamicton and the host sediments will strongly control their ability to flow and mix during emplacement. In theory the density of the diamicton will be influenced by factors including porewater content and pressure, as well as the modal proportions of larger skeletal grains (granule to pebble sized clasts). The viscosity ('stickiness') of the diamicton which will strongly effect its ability to be injected into the host sediments and will be influenced by the mineralogy of the matrix. For example, a sandy or silt-rich matrix will tend to dilate/liquefy more easily, whereas a clay-rich matrix would lead to a direct increase in viscosity due to the presence of either swelling clays and/or the electrostatic bonds between the clays leading to an increase in cohesion of the diamicton. In areas where the host sediments are relatively 'dry' or have a higher cohesive strength, injection of the diamicton along bedding caused very little or no disturbance leading to sharp, planar contacts. Where the diamicton was being emplaced into areas of softer/'wetter' laminated sediment, frictional drag/shear focused along the contacts would lead to deformation ranging from gentle, open warping through to more complex folding of the boundary and the formation of the observed lobate to highly involuted boundaries (Figs. 4, 5, 6, 7 and 8). Subsequent compaction and loading by the overlying ice could have led to further soft-sediment deformation (convolution) of these boundaries.

In areas where the host clays and silts are wet or even water saturated, then these laminated sediments appear to have also undergone localised liquefaction and remobilisation (see Figs. 16 and 17). Density contrasts between the diamicton and host sediments, coupled with the disturbance caused by the injection of the liquefied diamicton is thought to have led directly to the liquefaction of the silts and partial (incomplete) mixing of these sediments with the matrix of the diamicton. Turbulent flow caused by the forceful injection of the potentially overpressurised diamicton would have resulted in its simultaneous fragmentation and the formation of rounded to irregular till pebbles which are immediately incorporated into the fluidised matrix (Fig. 16). Turbulent flow within the matrix of the diamicton is indicated by the preservation of early formed turbate structures within the microlithons separating the S1 clast microfabric domains. The switch from massive, coherent layers of diamicton to more fragmented and "pebbly textured" may also reflect changes in the supply (injection rate) of 
liquefied sediment being injected. A steady, constant stream of liquefied sediment being injected into the host is more likely to form a more extensive coherent layer. Whereas, a "pulsed" or rapidly "fluctuating" supply is more likely to result in the disruption of a wet sediment host, as well as formation of a discontinuous or fragmented layer of diamicton. The water-rich nature of the sediments during deposition is supported by the occurrence of dewatering structures and veinlets composed of highly birefringent clay.

The 'partial mixing' process is best observed in sample R.248 (Fig. 9) where the whole of the diamicton layer has turbid, fragmentary appearance and here referred to as 'vinaigrette' texture (also see Figs. 4, 6, 7, 14, 16 and 17). Similar textures have been described from intrusive igneous rocks where they develop in response to the interaction of two coeval, but compositionally different magmas, a process referred to as magma mingling (Jerram and Petford, 2011). Complete mixing of the liquefied diamicton with the host sediments appears to be "prevented" because the sequence dewatered and solidified well before the process reached completion. Solidification of the diamicton layers was accompanied by the imposition of the clast microfabrics (see Figs. 4 to 8 ) and late-stage injection of the crosscutting water-escape features and veinlets of clay (Figs. 14 and 17). Simple shear imposed by the overriding ice would have also resulted in the variable rotation of pebbles leading to the formation of asymmetrical pressure shadows and grain alignments immediately adjacent to these large clasts. In both the Galmis and, to a lesser extent, Plumpe Farm tills the clast microfabrics are better developed within the thicker layers of diamicton (compare Figs. 4 and, 5 with Fig. 6; also see Fig. 16), consistent with these layers taking longer to dewater and allowing more time for deformation and foliation development.

The finely stratified nature of the tills at both Galmis and Plumpe Farm indicates that this process of injection of liquefied diamicton into a variably deformed host of laminated silt and clay occurred repeatedly and was not a single event. Consequently, any model for the evolution of thinly stratified subglacial tills needs to accommodate/include a method enabling the multiple injection of diamicton into still wet, laminated water lain silts and clays.

\section{Conceptual model involving liquefaction, injection, sediment deposition and deformation during basal sliding}

Phillips et al. (2007) concluded that the thinly stratified till at Plumpe Farm formed as the Southern Uplands ice advanced over water-saturated glaciofluvial to glaciolacustrine sediments laid down in a number of ice-marginal lakes ponded against high ground to the east (Trotter, 1929; Trotter and Hollingworth, 1932). These authors argued that forward motion of the ice was facilitated by the development of a water lubricated surface at the icebed interface, leading to basal sliding over the pre-existing water-saturated sediments. The development of a water lubricated zone at the base of the ice will dramatically reduce the amount of shear translated into the underlying soft sediments, therefore placing a limit on the intensity of deformation recorded within the substrate. Furthermore perturbations in the base of the ice and/or fluctuations in the amount of meltwater can lead to the trapping or ponding of water along the ice-bed interface. Any sediment carried by this trapped meltwater will then 
begin to settle out resulting in the potential deposition of finely laminated sediments at the ice-bed interface. As a result, the thinly stratified subglacial tills exposed at Galmis and Plumpe Farm may both have formed as a result of the development of a water lubricated zone at the ice sediment interface and provide a detailed record of the processes occurring during basal sliding (Fig. 18). The micromorphology of these stratified tills has yielded valuable insights into the processes occurring during basal sliding of ice over a soft-sediment bed.

Sedimentary structures preserved within the silt and clay layers in both the Galmis and Plumpe Farm tills are consistent with a waterlain origin for these fine-grained sediments. These finely laminated sediments form an integral part of these subglacial sequences of tills are therefore interpreted as having been deposited by water trapped along the ice-bed interface (Fig. 18). Ponding of meltwater within cavities at the base of the ice is thought to occur in between individual "sliding events" when the ice is static and coupled to its bed. Dropstones present within the laminated silts and clays are interpreted as representing sand and small pebble sized clasts released during the melting of the overlying ice. The ponding or trapping of meltwater at the ice-bed interface between basal sliding events contrasts slightly with the models proposed by Piotrowski and Tulaczyk (1999), Munro-Stasiuk (2000), Piotrowski et al., $(2004,2006)$ and Lesemann et al., (2010) who have suggested that thin stringers of sorted coarser grained sediments (sands and gravels) present within some till sequences are deposited during periods when the ice decoupled from its bed. The clay- and slit-rich nature of the laminated sediments within both the Galmis and Plumpe Farm stratified tills indicates that these sediments were deposited from slow moving and/or standing water. Individual decoupling or basal sliding 'slip events' are likely to be short lived resulting in a stick-slip style of glacier motion. Deposition of clays by settling out of these fines requires an extended time period, therefore it is considered that this requires the meltwater to be ponded between the ice and its bed, in between the individual basal sliding events (cf. Fuller and Murray 2000). Furthermore this suggests that the 'stick' or coupled phase of the basal sliding process is far longer in duration to that of the short lived, decoupled 'slip event'. As the ice decouples from its bed, the meltwater ponded/trapped at the ice-bed interface would be free to drain.

The onset of a basal sliding 'slip event' is likely to be preceded by an increase in meltwater content/pressure within the sediments immediately below the ice, potentially leading to the variable saturation of these deposits. The amount of meltwater being introduced into the sediments will be strongly dependent upon their permeability with clayrich diamictons/layers acting as an aquatard restricting the ingress of meltwater and leading to its concentration at the ice-bed interface. During a 'slip event' the ice mass decouples from its bed sliding forward on a water lubricated surface. The combination of increase meltwater contents/pressures within the bed, allied to the sudden lowering of overburden pressure exerted by the ice as it decouples from its bed is thought to promote favorable conditions for localised liquefaction within the till. Variations in the overburden pressure beneath the glacier, coupled with shear imposed by the overriding ice as it starts to recouple with the bed results in the mobilization and displacement of the liquefied diamicton which is injected along bedding within the laminated silts and sands (Fig. 18). Injection of the diamicton into 
wet or water saturated silts and clays resulted in partial liquefaction and partial mixing of these fine-grained sediments into the matrix of the diamicton (Figs. 16 and 18). Density contrasts between the two liquefied sediments, coupled with a variation in sediment supply/injection rate, led to the development of a complex 'vinaigrette-like' texture comprising rounded to irregular till pebbles within a matrix of variably homogenised silty clay (Fig. 16). Recoupling of the ice with its bed at the end of the 'slip event' would result in increasing amounts of shear being transmitted into the underlying sediments, leading to localised folding and thrusting within the laminated silts and clays, and imposition of a variably developed clast microfabric in the diamicton layers. Small-scale deformation structures such as asymmetrical pressure shadows and tails developed upon skeleton grains, asymmetrical folds, deformed till pebbles and quarter folds (Figs. 18b to f, respectively) can, with care, be used as kinematic indicators recording the sense of movement of the overriding ice (Fig. 18).

Variation in E1 and E2 eigenvalues obtained for clast microfabrics (Fig. 10) present within the diamicton layers reflects a change in the intensity of fabric development due to the partitioning of deformation imposed by the overriding ice as it recouples with the bed. In general, however, the clast microfabrics are relatively weakly developed, reflected in the relatively low eigenvalues obtained for the clast microfabrics (Table 1, Fig. 10). This may tentatively be used to suggest that the amount of shear transmitted into the bed by the overriding ice is also low with forward movement being taken up by sliding on the water-rich film at the base of the ice and, to a lesser extent, flow of the liquefied diamicton. No obvious strain markers are present in the diamicton. Several workers have attempted to use the relative abundance of selected microstructures, such as microshears and grain stacks, as a proxy for strain in subglacial diamictons (Larsen et al., 2006, 2007; Narloch et al., 2012). However, the development of such structures can be strongly lithologically controlled (e.g. microshears defined by a unistrial plasmic will only form in clay-rich sediments) and their identification is considered to be qualitative and potentially subjective (Leighton et al., 2012; Neudorf et al., 2013). As a result a reliable method of estimating shear strain from thin sections of deformed glacial sediments is yet to be established. One possible method which may prove reliable is the use of shear strain curves established from experimental deformation studies such as those of Thomason and Iverson (2006). A preliminary estimate of the shear strains recorded by the Galmis and Plumpe Farm tills has been made using the shear strain curves for the gravelly Batestown till and sand-rich Douglas till published by Thomason and Iverson (2006) (see Fig. 19). These authors demonstrated that clast fabrics developed within tills develop at relatively low values of shear strain, indicating the shear strains recorded during subglacial deformation are much lower than previously expected. Fig. 19 shows a plot of the range of E1 eigenvalues calculated for clast microfabrics within the Galmis (Fig. 19a) and Plumpe Farm (Fig. 19b) tills projected onto the shear strain curves of Thomason and Iverson (2006). The data suggests that the clast microfabrics present within these tills may have developed as a result of shear strains of less than 15 . If these estimates are correct it would suggest that the amount of shear transmitted into the soft-sediment bed during basal sliding is relatively low (c.f. Thomason and Iverson, 2006; Larsen et al., 2006; Narloch et al., 2012), allowing the preservation of the fine-scale stratification, comprising 
alternating diamicton and laminated silt and clay layers, observed within the Galmis and Plumpe Farm tills.

\section{Conclusions}

The results of a detailed micromorphological study of thinly stratified subglacial tills exposed at Galmis in Switzerland and Plumpe Farm, near Gretna in SW Scotland has revealed a complex history of deformation, liquefaction and sedimentation during repeated phases of basal sliding as the ice overrode a soft-sediment bed. The stratification within these tills comprises alternating layers of massive to weakly foliated diamicton and variably deformed, laminated silt and clay. Elevated meltwater contents/pressures encountered immediately prior to, and during basal sliding promoted localised liquefaction of the diamictons. Decoupling of the ice mass from its bed enabled the injection of this liquefied diamicton along the ice-bed interface and/or into the laminated sediments immediately adjacent to this boundary. These laminated silts and clays are interpreted as record the settling out of fines (clay, slit) from meltwater trapped along the ice-bed interface after an individual phase of basal sliding has ceased. Injection of the pressurised till into the locally water saturated silts and clays resulted in partial liquefaction and incomplete mixing of these fine-grained sediments with the diamicton. Density contrasts between the two liquefied sediments led to the development of a complex 'vinaigrette-like' texture comprising rounded to irregular till pebbles within a matrix of variably homogenised silty clay. Recoupling of the ice with its bed led to localised folding and thrusting within the laminated silts and clays, hydrofracturing and injection of a network of sand-filled veins, and the imposition of a variably developed clast microfabric in the diamicton layers. Analysis of the clast microfabrics indicates that the intensity of these fabrics is highly variable reflecting the variation in the intensity of deformation imposed by the overriding ice. Estimates of the strains imposed on these stratified tills indicates that the amount of shear transmitted into the soft-sediment bed during basal sliding is relatively low, allowing the preservation of the fine-scale stratification, comprising alternating diamicton and laminated silt and clay layers, observed within the Galmis and Plumpe Farm tills.

\section{Acknowledgements}

This paper is published with the permission of the Executive Director of the British Geological Survey (NERC) with the work forming part of ERP's IMP research project. Jonathan Lee and Andrew Finlayson are thanked for their comments on an earlier version of the manuscript. John Menzies and Wlodzimierz Narloch are both thank for their constructive reviews of this paper. ERP is an associate member of the Centre for Micromorphology, Queen Mary, University London. 


\section{References}

Baroni, C., Fasano, F., 2006. Micromorphological evidence of warm-based glacier deposition from the Ricker Hills Tillite (Victoria Land, Antarctica). Quaternary Science Reviews. 25, 976-992.

Benn, D.I., Evans, D.J.A., 2010. Glaciers and Glaciation. Hodder, London.

Crausaz, Ch.U., 1958 Géologie de la région de Fribourg. Bulletin de la Société Fribourgeoise des Sciences Naturelles 48, 5-117.

Denis, M., Guiraud, M., Konaté, M., Buoncristiani, J.-F., 2010. Subglacial deformation and water-pressure cycles as a key for understanding ice stream dynamics: evidence from the Late Ordovician succession of the Djado Basin (Niger). International Journal of Earth Science (Geol Rundsch) 99, 1399-1425.

Evans, D.J., Phillips, E.R., Hiemstra, J.F., Auton, C.A., 2006. Subglacial till: formation, sedimentary characteristics and classification. Earth-Science Reviews 78, 115-176.

Fischer, U.H., Clarke, G.K.C., 1997. Stick-slip sliding behaviour at the base of a glacier. Annals of Glaciology 24, 390-396.

Fischer, U.H., Clarke, G.K.C., Blatter, H., 1999. Evidence for temporally varying 'sticky spots' at the base of Trapridge Glacier, Yukon Territory, Canada. Journal of Glaciology 45, 352-360.

Fuller, S., Murray, T., 2002. Sedimentological investigations in the forefield of an Icelandic surge-type glacier: implications for the surge mechanism. Quaternary Science Reviews 21, 1503-1520.

Hiemstra, J.F., van der Meer, J.J.M., 1997. Pore-water controlled grain fracturing as an indicator for subglacial shearing in tills. Journal of Glaciology 43, 446-454.

Hiemstra, J.F., Rijsdijk, K.F., Evans, D.J.A., van der Meer, J.J.M., 2005. Integrated microand macro-scale analyses of Last Glacial maximum Irish Sea diamicts from Abermaw and Treath y Mwnt, Wales, UK. Boreas 34, 61-74.

Huddart, D., Glasser, N.F., 2002. The Devensian glacial record; Introduction. In: Huddart, D., Glasser, N.T. (eds.). Quaternary of Northern England, Geological Conservation Review Series 25. Joint Nature Conservation Committee, Peterborough, pp. 87-131.

Iverson, N.R., Hoojer, T.S., Hooke, R. LeB., 1996. A laboratory study of sediment deformation: stress heterogeneity and grain-size evolution. Annals of Glaciology. 22, 167175 .

Jerram, D., Petford, N., 2011. The Field Description of Igneous Rocks (second edition), Wiley and Blackwell, Chichester. ISBN 978-0-470-02236-8. 
Khatwa, A., Tulaczyk, S., 2001. Microstructural interpretations of modern and Pleistocene subglacially deformed sediments: the relative role of parent material and subglacial processes. Journal of Quaternary Science 16, 507-517.

Larsen, N.K., Piotrowski, J.A., Christiansen, F., 2006. Microstructures and micro-shears as proxy for strain in subglacial diamicts: implications for basal till formation. Geology. 34, 889-892.

Larsen, N.K., Piotrowski, J.A., Menzies, J., 2007. Microstructural evidence of low-strain, time transgressive subglacial deformation. Journal of Quaternary Science. 22, 593-608.

Lee, J.R., Phillips, E.R., 2008. Progressive soft sediment deformation within a subglacial shear zone - a hybrid mosaic-pervasive deformation model for Middle Pleistocene glaciotectonised sediments from eastern England. Quaternary Science Reviews 27, 13501362.

Leighton, I.D., Hiemstra, J.F., Weidemann, C.T., 2012. Recognition of micro-scale deformation structures in glacial sediments - pattern perception, observer bias and the influence of experience. Boreas, 10.1111/j.1502-3885.2011.00246.x. ISSN 0300-9483.

Lesemann, J-E., Alsop, G.I., Piotrowski, J.A., 2010. Incremental subglacial meltwater sediment deposition and deformation associated with repeated ice-bed decoupling: a case study from the Island of Funen, Denmark. Quaternary Science Reviews 29, 3212-3229.

Menzies, J., 2000. Micromorphological analyses of microfabrics and microstructures indicative of deformation processes in glacial sediments. In: A.J. Maltman, B. Hubbard, M.J. Hambrey (eds.). Deformation of glacial materials. Geological Society of London, Special Publication 176, 245-257.

Menzies, J., 2012. Strain pathways, till internal architecture and microstructures perspectives on a general kinematic model - a 'blueprint' for till development. Quaternary Science Reviews 50, 105-124.

Menzies, J., Maltman, A.J., 1992. Microstructures in diamictons - evidence of subglacial bed conditions. Geomorphology 6, 27-40.

Menzies, J., Zaniewski, K., Dreger, D., 1997. Evidence from microstructures of deformable bed conditions within drumlins, Chimney Bluffs, New York State. Sedimentary Geology 111, 161-175.

Menzies, J., van der Meer, J.J.M., Rose, J., 2006. Till - a glacial "tectomict", a microscopic examination of a till's internal architecture. Geomorphology 75, 172-200.

Menzies, J., Ellwanger, D., 2010. Insights into subglacial processes inferred from the micromorphological analyses of complex diamicton stratigraphy near Illmensee-Lichtenegg, Höchsten, Germany. Boreas 10,40, 271-288. 
Merritt, J.W., Auton, C.A., 2000. An outline of the lithostratigraphy and depositional history of Quaternary deposits in the Sellafield district, West Cumbria. Proceedings of the Yorkshire Geological Society 53, 129-154.

Murray, T., Dowdeswell, J.A., 1992. Water through flow and physical effects of deformation on sedimentary glacier beds. Journal of Geophysical Research 97 (B6), 8993-9002.

Munro-Stasiuk, M.J., 2000. Rhythmic till sedimentation: evidence for repeated hydraulic lifting of a stagnant ice mass. Journal of Sedimentary Research 70, 94-106.

Narloch, W., Piotrowski, J.A., Wysota, W., Larsen, N.K., Menzies, J., 2012. The signature of strain magnitude in tills associated with the Vistula Ice Stream of the Scandinavian Ice Sheet, central Poland. Quaternary Science Reviews 57, 105-120.

Narloch, W., Wysota, W., Piotrowski, J.A., 2013. Sedimentological record of subglacial conditions and ice sheet dynamics of the Vistula Ice Stream (north-central Poland) during the Last Glaciation. Sedimentary Geology 293, 30-44.

Neudorf, C. M., Brennand, T. A., Lian, O. B., 2013. Till-forming processes beneath parts of the Cordilleran Ice Sheet, British Columbia, Canada: macroscale and microscale evidence and a new statistical technique for analysing microstructure data. Boreas, 10.1111/bor.12009. ISSN 0300-9483.

Passchier, C.W., Trouw, R.A.J., 1996. Microtectonics. Springer.

Phillips, E., Merritt, J.W., Auton, C.A., Golledge, N.R., 2007. Microstructures developed in subglacially and proglacially deformed sediments: faults, folds and fabrics, and the influence of water on the style of deformation. Quaternary Science Reviews 26, 1499-1528.

Phillips, E.R., Auton, C.A., 2000. Micromorphological evidence for polyphase deformation of glaciolacustrine sediments from Strathspey, Scotland. In: Maltman, A.J., Hubbard, B., Hambrey, M.J. (eds.). Deformation of glacial materials. The Geological Society of London, Special Publication 176, 279-291.

Phillips, E., Merritt, J., 2008. Evidence for multiphase water-escape during rafting of shelly marine sediments at Clava, Inverness-shire, NE Scotland. Quaternary Science Reviews 27, 988-1011.

Phillips, E.R., van der Meer, J.J.M., Ferguson, A., 2011. A new 'microstructural mapping' methodology for the identification and analysis of microfabrics within glacial sediments. Quaternary Science Reviews 30, 2570-2596.

Phillips, E., Lee, J.R. 2011. Description, measurement and analysis of glacitectonically deformed sediments. In: Phillips, E., Lee, J.R., Evans, H.M. (eds.). Glacitectonics - Field Guide. Quaternary Research Association. 
Phillips, E., Everest, J., Reeves, H., 2013. Micromorphological evidence for subglacial multiphase sedimentation and deformation during overpressurized fluid flow associated with hydrofracturing. Boreas 42, 395-427.

Piotrowski, J.A., Tulaczyk, S., 1999. Subglacial conditions under the last ice sheet in northwest Germany: ice-bed separation and enhanced basal sliding? Quaternary Science Reviews 18, 737-751.

Piotrowski, J.A., Larsen, N.K., Junge, F., 2004. Soft subglacial beds: a mosaic of deforming and stable spots. Quaternary Science Reviews 23, 993-1000.

Piotrowski, J.A., Larsen, N.K., Menzies, J., Wysota, W., 2006. Formation of subglacial till under transient bed conditions: deposition, deformation, and basal decoupling under a Weichselian ice sheet lobe, central Poland. Sedimentology 53, 83-106.

Roberts, D.H., Hart, J.K., 2005. The deforming bed characteristics of a stratified till assemblage in north East Anglia, UK: investigating controls on sediment rheology and strain signatures. Quaternary Science Reviews 24, 123-140.

Thomason, J.F., Iverson, N.R., 2006 Microfabric and micro-shear evolution in deformed till. Quaternary Science Reviews 25, 1027-1038.

Trotter, F.M., 1922. Report from the Cumberland District. In: Summary of Progress of the Geological Survey of Great Britain for 1921. 46-48.

Trotter, F.M., Hollingworth, S.E., 1932. The glacial sequence in the North of England. Geological Magazine 69, 374-380.

van der Meer, J.J.M., 1979. Complex till sections in the western Swiss Plain. In: Ch. Schlüchter (ed.). Moraines and varves. A.A. Balkema, Rotterdam. 265-269.

van der Meer, J.J.M., 1982. The Fribourg area. A study in Quaternary Geology and soil development. $\mathrm{PhD}$ thesis, University of Amsterdam.

van der Meer, J.J.M., 1987. Micromorphology of glacial sediments as a tool in distinguishing genetic varieties of till. Geological Survey of Finland Special Paper 3, 77-89.

van der Meer, J.J.M., 1993. Microscopic evidence of subglacial deformation. Quaternary Science Reviews 12, 553-587.

van der Meer, J.J.M., Verbers, A.L.L.M., Warren, W.P., 1994. The micromorphological character of the Ballycroneen Formation (Irish Sea Till): a first assessment. In: Warren, W.P., Croot, D.G. (eds.). Formation and deformation of glacial deposits. Balkema, Rotterdam, pp. 39-49.

van der Meer, J.J.M., Menzies, J., Rose, J., 2003. Subglacial till, the deformable glacier bed. Quaternary Science Reviews 22, 1659-1685. 
van der Meer, J.J.M., Kjær, K.H., Krüger, J., Rabassa, J., Kilfeather, A.A., 2009. Under pressure: clastic dykes in glacial settings. Quaternary Science Reviews 28, 708-720.

van der Wateren, F.M., 1999. Structural geology and sedimentology of the Heiligenhafen till section, Northern Germany. Quaternary Science Reviews 18, 1625-1639.

van der Wateren, F.M., Kluiving, S.J., Bartek, L.R., 2000. Kinematic indicators of subglacial shearing. In: A.J. Maltman, B. Hubbard, M.J. Hambrey (eds.) Deformation of glacial materials. Geological Society of London, Special Publication. 176, 259-278.

Vaughan-Hirsch, D.P., Phillips, E., Lee, J.R., Hart, J.K., 2013. Micromorphological analysis of poly-phase deformation associated with the transport and emplacement of glaciotectonic rafts at West Runton, north Norfolk, UK. Boreas 42, 376-394.

Winberry, P.J., Anandakrishnan, S., Alley, R.B., Bindschadler, R.A., King, M.A. 2009. Basal mechanics of ice streams: Insights from the stick-slip motion of Whillans Ice Stream, West Antarctica. Journal of Geophysical Research: Earth Surface 114, F01016, doi:10.1029/2008JF001035.

\section{Figures}

Fig. 1. (a) Diagram showing the distribution of the main sedimentary units exposed in the gravel pit, Galmis, Switzerland (after van der Meer, 1979, 1982). The location of the samples R.163A to D, R.164, R.165, R.166, R.248 and R.419 are also shown; (b) Photograph of the lower part of the till sequence comprising massive to weakly bedded diamicton overlain by thinly stratified diamicton. The boundary between the two units is sharp; (c) Photograph showing the layering which characterises the stratified diamicton; and (d) Small-scale asymmetrical fold deforming a laminated silt and clay layer within the thinly stratified diamicton.

Fig. 2. Simplified lithological log of the Quaternary deposits exposed at Plumpe Farm near Gretna (after Phillips et al., 2007). Photograph shows the laminated sands and silts and clays (Unit II) overlain by diamicton (Unit III). The location of samples N2840, N2841, N2842 and N2843 are also shown.

Fig. 3. Microstructural map and high resolution scan of thin section R.166 taken from the lower, gravelly diamicton exposed at Galmis gravel pit (see text for details). The orientation of the long axes of the fine sand to pebble sized clasts included within this diamicton are shown in the series of rose diagrams. Area A - upper part of the thin section; Area B - lower half of the thin section; Area $\mathrm{C}$ - area outlined in red and dominated by the anastomosing, steeply inclined to subvertical S4 fabric.

Fig. 4. Microstructural map and high resolution scan of thin section R.164 taken from the thinly stratified diamicton exposed at Galmis gravel pit (see text for details). The orientation of the long axes of the fine sand to pebble sized clasts included within the diamicton layers (labeled A to D) diamicton are shown in the series of rose diagrams. Inset is a false colour 
image of the thin section highlighting the distribution of the clay-rich laminae within this stratified till.

Fig. 5. Microstructural map and high resolution scan of thin section R.163A taken from the thinly stratified diamicton exposed at Galmis gravel pit (see text for details). The orientation of the long axes of the fine sand to pebble sized clasts included within the diamicton layers (labeled A to E) diamicton are shown in the series of rose diagrams. Inset is a false colour image of the thin section highlighting the distribution of the clay-rich laminae within this stratified till.

Fig. 6. Microstructural map and high resolution scan of thin section R.163B taken from the thinly stratified diamicton exposed at Galmis gravel pit (see text for details). The orientation of the long axes of the fine sand to pebble sized clasts included within the diamicton layers (labeled A to F) are shown in the series of rose diagrams. Inset is a false colour image of the thin section highlighting the distribution of the clay-rich laminae within this stratified till.

Fig. 7. Microstructural map and high resolution scan of thin section R.163C taken from the thinly stratified diamicton exposed at Galmis gravel pit (see text for details). The orientation of the long axes of the fine sand to pebble sized clasts included within the diamicton layers (labeled A to F) are shown in the series of rose diagrams. Inset is a false colour image of the thin section highlighting the distribution of the clay-rich laminae within this stratified till.

Fig. 8. Microstructural map and high resolution scan of thin section R.163D taken from the thinly stratified diamicton exposed at Galmis gravel pit (see text for details). The orientation of the long axes of the fine sand to pebble sized clasts included within the diamicton layers (labeled A and B) are shown in the series of rose diagrams. Inset is a false colour image of the thin section highlighting the distribution of the clay-rich laminae within this stratified till.

Fig. 9. Microstructural map and high resolution scan of thin section R.248 taken from the thinly stratified diamicton exposed at Galmis gravel pit (see text for details). The orientation of the long axes of the fine sand to pebble sized clasts included within the diamicton and orientation of the microfaults developed within the adjacent laminated silt and clay layer are shown in the series of rose diagrams. Inset is a false colour image of the thin section highlighting the distribution of the clay-rich laminae within this stratified till.

Fig. 10. Graphs showing the variation in E1 and E2 eigenvalues calculated from the clast orientation data obtained from the diamicton layers within samples of thinly stratified diamicton: (a) sample R.163A; (b) sample R.163B; (c) sample R.163C; and (d) sample R165. Distance $(\mathrm{mm})=$ distance measured from base of tin section to the midline of the diamicton layer.

Fig. 11. Microstructural map and high resolution scan of thin section R.165 taken from the bedded diamicton forming the upper part of the glacigenic sequence exposed at Galmis gravel pit (see text for details). The orientation of the long axes of the fine sand to pebble sized clasts included within the diamicton are shown in the series of rose diagrams. Area A - 
upper part of the thin section; Area B - central part of the thin section; Area C - lower part of the thin section.

Fig. 12. Microstructural map and high resolution scan of thin section R.419 taken from the bedded diamicton forming the upper part of the glacigenic sequence exposed at Galmis gravel pit (see text for details). The orientation of the long axes of the fine sand to pebble sized clasts included within the diamicton are shown in the series of rose diagrams. Area A upper part of the thin section; Area B - lower part of the thin section. Inset is a false colour image of the thin section highlighting the distribution of the clay-rich laminae within this diamicton.

Fig. 13. High resolution scans of thin sections $N 2840$ (a) and N2841 (b) taken from the laminated glaciofluvial/glaciolacustrine sediments forming the lower part of the glacigenic sequence exposed at Plumpe Farm (see text for details).

Fig. 14. Microstructural map and high resolution scan of thin section N2842 taken from the stratified basal part of the till exposed at Plumpe Farm (see text for details). The orientation of the long axes of the fine sand to pebble sized clasts included within the diamicton are shown in the series of rose diagrams. Layer 4 - pebbly textured diamicton in the lower part of the thin section; Layer 2 - thick layer of diamicton forming the central part of the thin section.

Fig. 15. Microstructural map and high resolution scan of thin section N2843 taken from the stratified basal part of the till exposed at Plumpe Farm (see text for details). The orientation of the long axes of the fine sand to pebble sized clasts included within the diamicton are shown in the series of rose diagrams. Layer 3 - upper part of the thin section; Layer 1 - lower part of the thin section.

Fig. 16. Schematic diagram showing the detailed internal microstructure of the thinly stratified till exposed at Galmis based upon the microstructural maps constructed for the thin sections R.164, R.163A to D, R.166 and R.248 (see text for details).

Fig. 17. Schematic diagram showing the detailed internal microstructure of the laminated glaciofluvial/glaciolacustrine sediments and overlying stratified diamicton exposed at Plumpe Farm based upon the microstructural maps constructed for the thin sections N2840, N2841, N2842 and N2843 (see text for details).

Fig. 18. (a) 3D block diagram showing the proposed conceptual model for basal sliding over a soft-sediment bed involving the shear induced deformation, liquefaction and injection of diamicton and deposition of laminated silt and clay due to ponding of meltwater between phases of basal sliding (see text for details). Figs (b) to (g) show the range of microstructures which can be used as potential kinematic indicators developed in response to basal sliding.

Fig. 19. Plot of E1 eigenvalue against shear strain. The shear strain curves for the Batestown (gravelly) and Douglas (sand-rich) tills are taken from Thomason \& Iverson (2006) and are used to obtain an estimate of the range of shear strains encountered by the tills exposed at Galmis (a) and Plumpe Farm (b) during subglacial deformation. 


\section{Tables}

Table 1. Eigenvalues calculated from clast long axis orientation from the diamicton layers within the thinly stratified and thicker, more massive tills exposed at Galmis, Switzerland, and stratified till exposed at Plumpe Farm, near Gretna, Scotland. Distance $=$ distance in millimeters measured from bottom of thin section upwards to middle of a particular diamicton layer within the thinly stratified tills.

\begin{tabular}{|c|c|c|c|c|c|c|}
\hline $\begin{array}{c}\text { Thin section } \\
\text { number }\end{array}$ & Location & Area/layer & $\begin{array}{c}\text { Distance } \\
\text { (mm) }\end{array}$ & $\mathbf{N}$ & $\begin{array}{c}\text { Eigenvalue } \\
\text { E1 }\end{array}$ & $\begin{array}{c}\text { Eigenvalue } \\
\text { E2 }\end{array}$ \\
\hline R.163A & Galmis & A & 54 & 387 & 0.598781 & 0.401219 \\
\hline R.163A & Galmis & $\mathrm{B}$ & 32 & 93 & 0.656440 & 0.343560 \\
\hline R.163A & Galmis & $\mathrm{C}$ & 25 & 276 & 0.653917 & 0.346083 \\
\hline R.163A & Galmis & $\mathrm{D}$ & 10 & 111 & 0.648011 & 0.351989 \\
\hline R.163A & Galmis & $E$ & 5 & 78 & 0.561411 & 0.438589 \\
\hline R.163B & Galmis & A & 100 & 195 & 0.620720 & 0.379280 \\
\hline R.163B & Galmis & B & 83 & 115 & 0.539827 & 0.460173 \\
\hline R.163B & Galmis & $\mathrm{C}$ & 67 & 175 & 0.615772 & 0.384228 \\
\hline R.163B & Galmis & $\mathrm{D}$ & 45 & 268 & 0.558489 & 0.441510 \\
\hline R.163B & Galmis & $\mathrm{E}$ & 25 & 510 & 0.558583 & 0.441417 \\
\hline R.163B & Galmis & $\mathrm{F}$ & 3 & 167 & 0.609409 & 0.390591 \\
\hline R.163C & Galmis & $\mathrm{A}$ & 105 & 1608 & 0.519470 & 0.480530 \\
\hline R.163C & Galmis & B & 85 & 474 & 0.556773 & 0.443227 \\
\hline R.163C & Galmis & $\mathrm{C}$ & 70 & 621 & 0.536235 & 0.463765 \\
\hline R.163C & Galmis & $\mathrm{D}$ & 42 & 242 & 0.587370 & 0.412621 \\
\hline R.163C & Galmis & $\mathrm{E}$ & 29 & 453 & 0.577729 & 0.422271 \\
\hline R.163C & Galmis & $\mathrm{F}$ & 9 & 161 & 0.590186 & 0.409814 \\
\hline R.163D & Galmis & A & 62 & 681 & 0.576958 & 0.423042 \\
\hline R.163D & Galmis & B & 35 & 718 & 0.543095 & 0.456905 \\
\hline R.164 & Galmis & $\mathrm{A}$ & 50 & 389 & 0.552464 & 0.447536 \\
\hline R.164 & Galmis & B & 35 & 604 & 0.558958 & 0.441042 \\
\hline R.164 & Galmis & $\mathrm{C}$ & 19 & 962 & 0.524914 & 0.475086 \\
\hline R.164 & Galmis & $\mathrm{D}$ & 6 & 691 & 0.596842 & 0.403158 \\
\hline R.165 & Galmis & $\mathrm{A}$ & 60 & 937 & 0.573953 & 0.426047 \\
\hline R.165 & Galmis & $\mathrm{B}$ & 35 & 843 & 0.538680 & 0.461320 \\
\hline R.165 & Galmis & $\mathrm{C}$ & 15 & 830 & 0.599000 & 0.401000 \\
\hline R.166 & Galmis & $\mathrm{A}$ & 60 & 942 & 0.544948 & 0.455052 \\
\hline R.166 & Galmis & $\mathrm{B}$ & 25 & 1110 & 0.545030 & 0.454970 \\
\hline R.166 & Galmis & $\mathrm{C}$ & 50 & 1257 & 0.556132 & 0.443868 \\
\hline R.248 & Galmis & all & 50 & 2653 & 0.550879 & 0.449121 \\
\hline R.248 & Galmis & $\mathrm{A}$ & 50 & 1462 & 0.553592 & 0.446408 \\
\hline R.248 & Galmis & $\mathrm{B}$ & 50 & 1210 & 0.551136 & 0.448864 \\
\hline R.419 & Galmis & all & 50 & 1617 & 0.625496 & 0.374504 \\
\hline R.419 & Galmis & $\mathrm{A}$ & 40 & 1207 & 0.619129 & 0.380871 \\
\hline R.419 & Galmis & $\mathrm{B}$ & 15 & 398 & 0.673876 & 0.326124 \\
\hline $\mathrm{N} 2842$ & Plumpe Farm & all & - & 621 & 0.573103 & 0.426897 \\
\hline $\mathrm{N} 2842$ & Plumpe Farm & 2 & - & 308 & 0.571341 & 0.428659 \\
\hline $\mathrm{N} 2842$ & Plumpe Farm & 4 & - & 162 & 0.570688 & 0.429312 \\
\hline $\mathrm{N} 2843$ & Plumpe Farm & all & - & 1515 & 0.660238 & 0.339762 \\
\hline $\mathrm{N} 2843$ & Plumpe Farm & 1 & - & 447 & 0.631877 & 0.368123 \\
\hline $\mathrm{N} 2843$ & Plumpe Farm & 3 & - & 844 & 0.666872 & 0.333128 \\
\hline
\end{tabular}




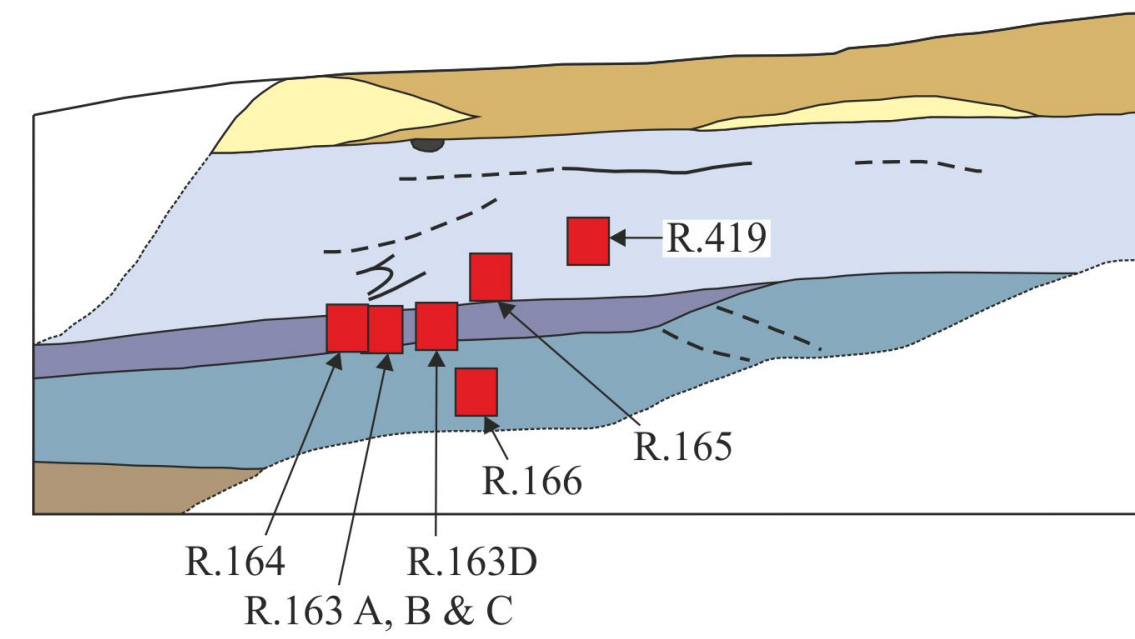

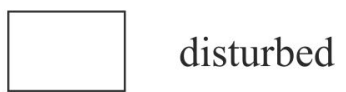

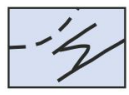

diamicton with sand layers (unit iii)

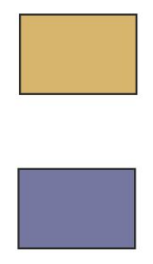

coarse gravel

layered diamicton (unit ii)

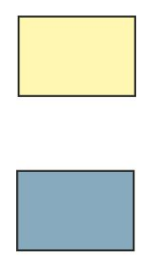

sand

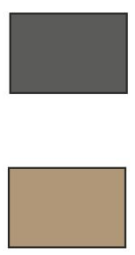

boulder

gravelly diamicton (unit i) sand and gravel
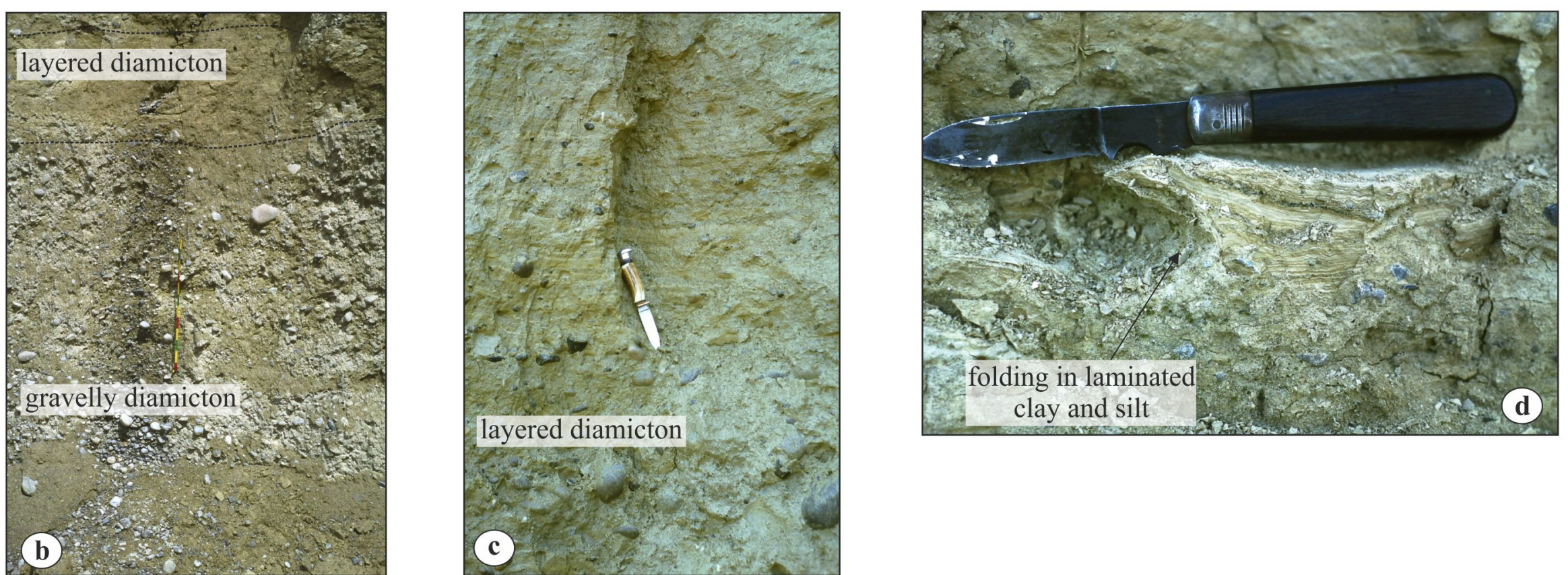
Description / Interpretation

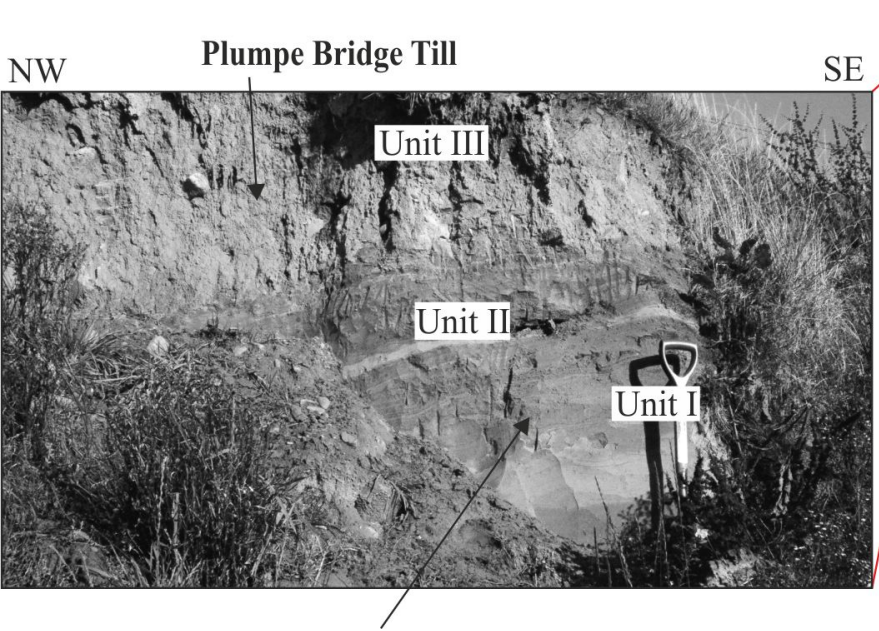

Plumpe Farm Sand \& Gravel

Location: Plumpe Farm, near Gretna

UNIT IV (soil)

UNIT III (Dmm)

Matrix-supported, reddish brown,

gravelly sandy diamicton

Glacigenic deposit: subglacial diamicton

UNIT II (Sh/Fl)

Hard, planar laminated sand, silt and silty clay Over-ridden glaciolacustrine

or glaciofluvial sediment

\section{UNIT I (Sh/FI)}

Compact, reddish brown silty sand and silt, uppermost $50 \mathrm{~cm}$ laminated Glaciolacustrine or glaciofluvial sediment

Fig. 2 
minor folding $\quad \begin{gathered}\text { thin clay and } \\ \text { carbonate veinlets }\end{gathered}$ sharp base $\quad$ overturned lamination

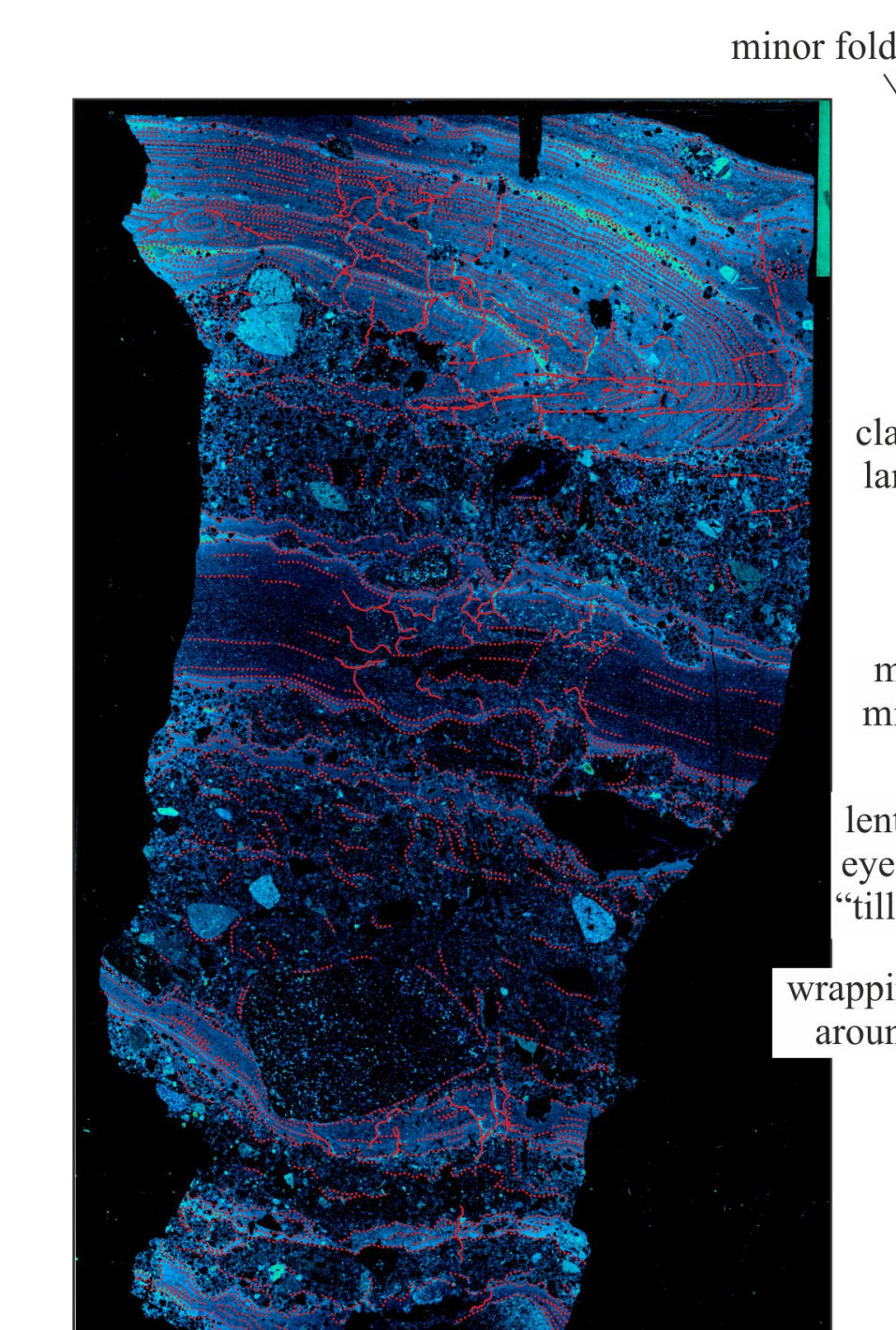

thin clay and
carbonate veinlets $\quad$ sharp base $\quad$ overturned lamination

thin clay and
carbonate veinlets sharp base $\quad$ overturned lamination

thin clay and
carbonate veinlets $\quad$ sharp base $\quad$ overturned lamination

alse colour image

Lithology

$\square$ clay-rich laminae

$\square$ diamicton

$\square$ laminated calcareous silt and cla

Microfabric domains

$\square$ crenulated (S1) fabric

$\square$ moderately inclined (S2) fabric

$\square$ apparently late (S3) fabric

..... bedding/layering

....... fold axes

-...- thrust

.......... grain alignments

clast microfabric
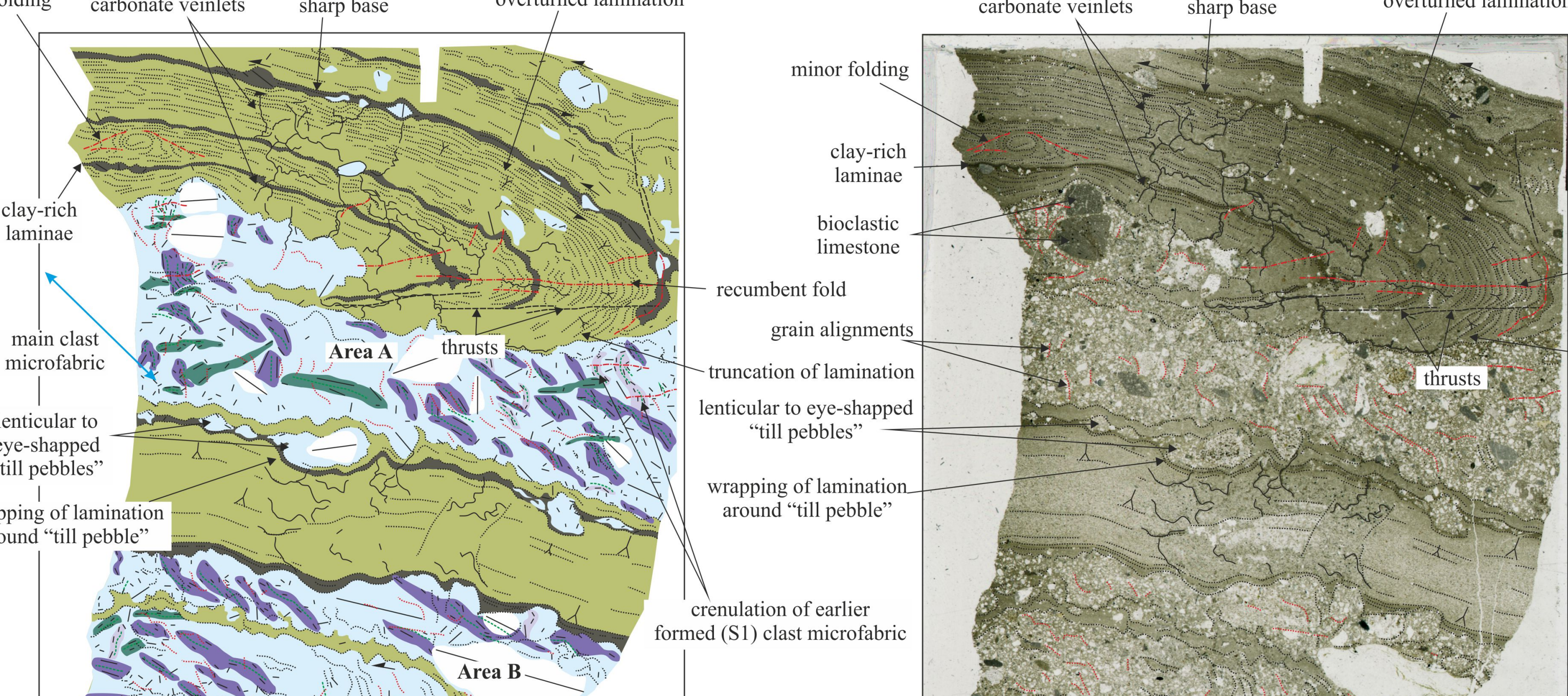

laminated, calcareous

silt and clay

recumbent fold

truncation of lamination

calcareous, matrix-supported, pebbly sandy diamicton

aminated, calcareous silt and clay

calcareous, matrix-supported, pebbly sandy diamicton
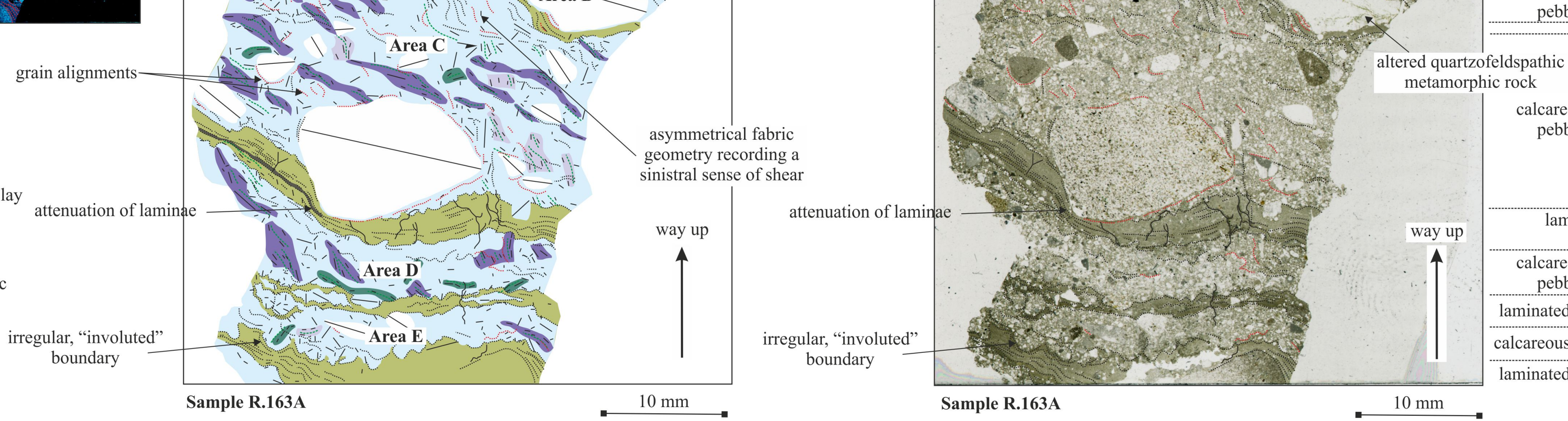

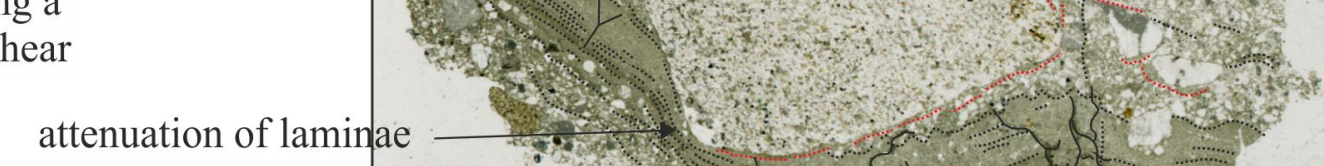

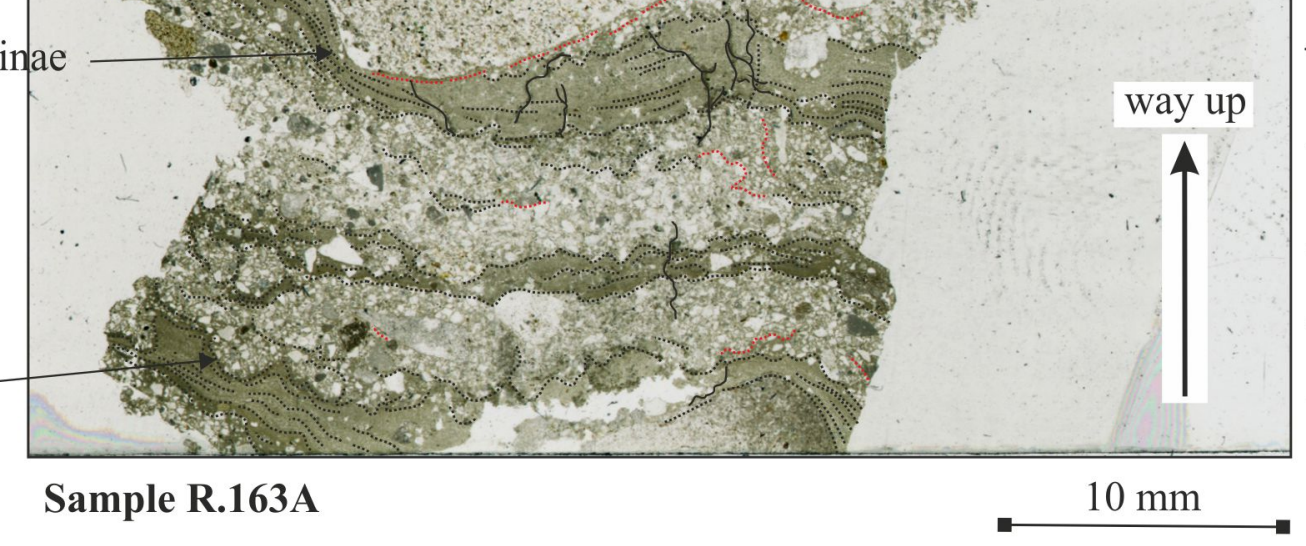
calcareous, matrix-supported,
pebbly sandy diamicton

rregular, "involuted" boundary
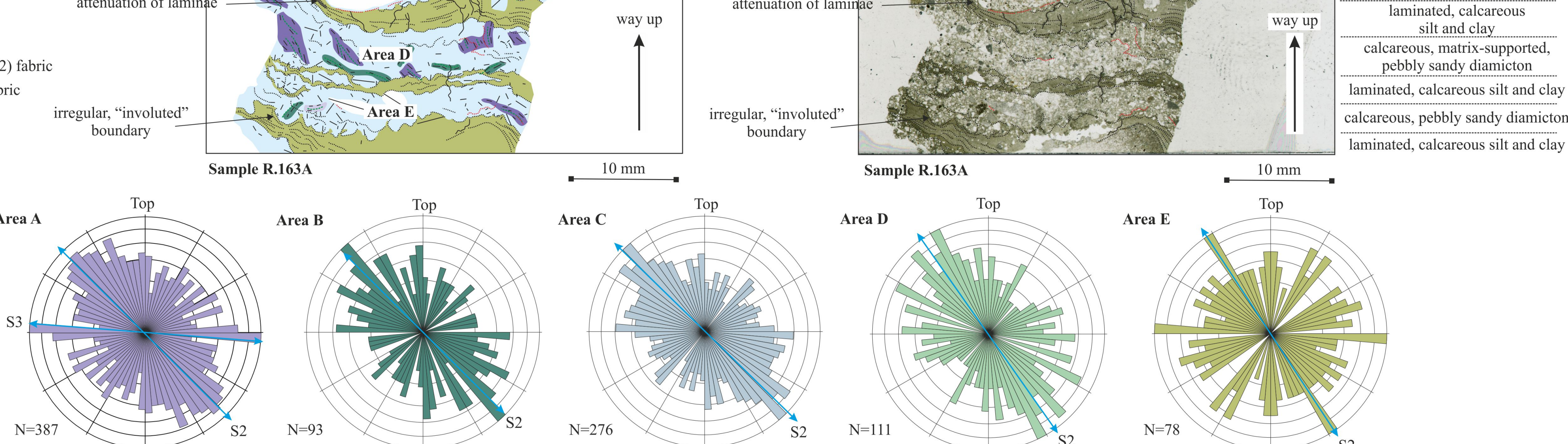


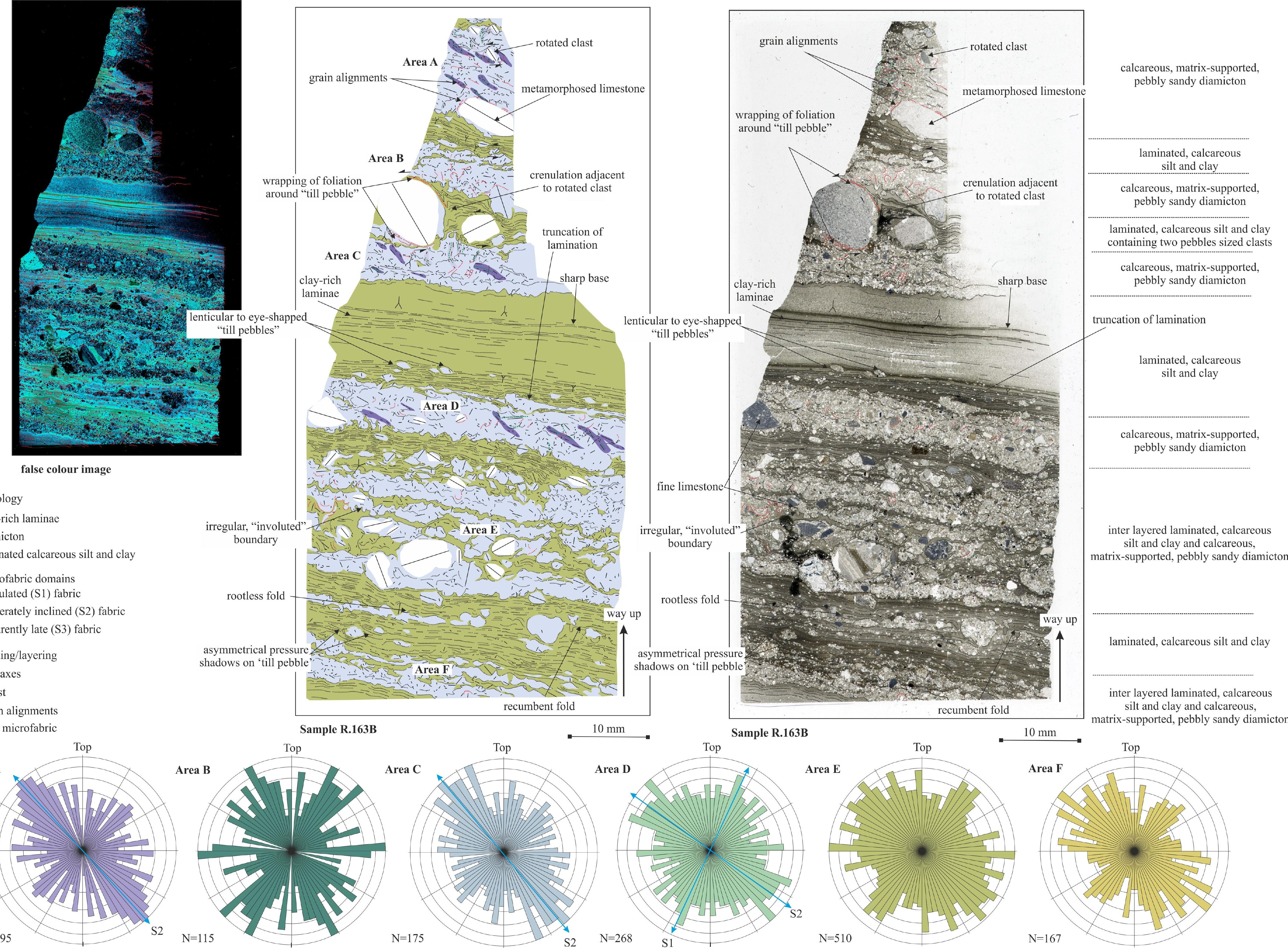




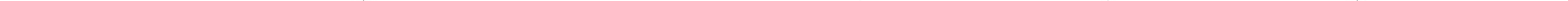


sample R163A

sample R163C $\quad$ sample R165
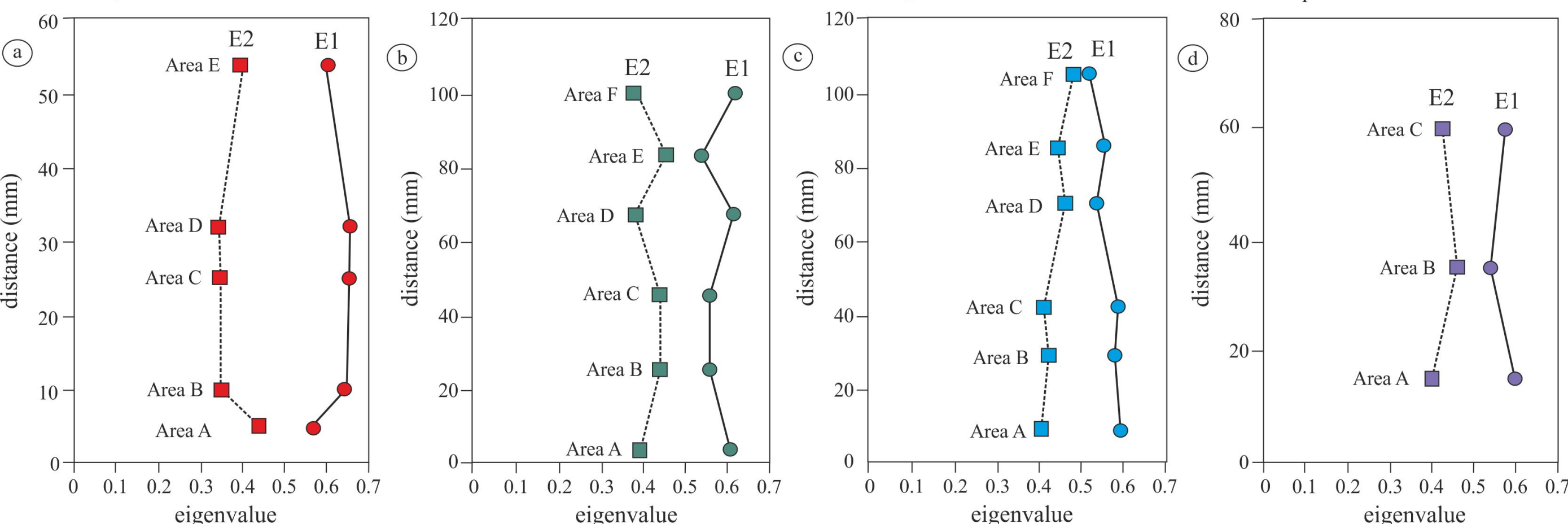
$x-\rightarrow$-erred alignment

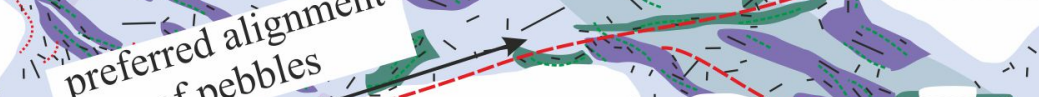

Area $\mathrm{B}$
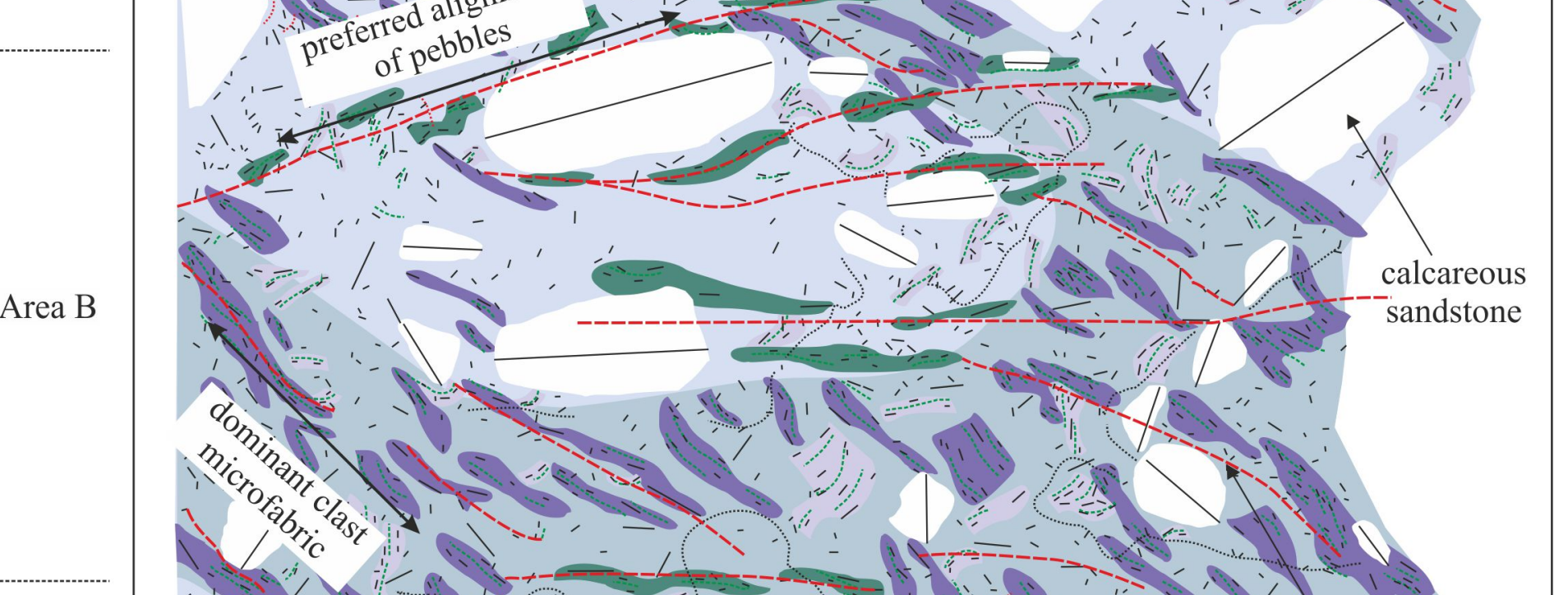

Area C

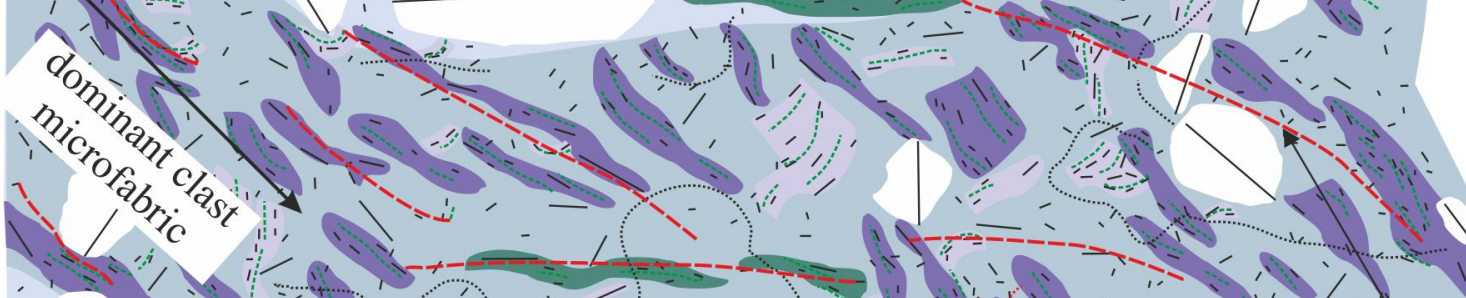

$+1$

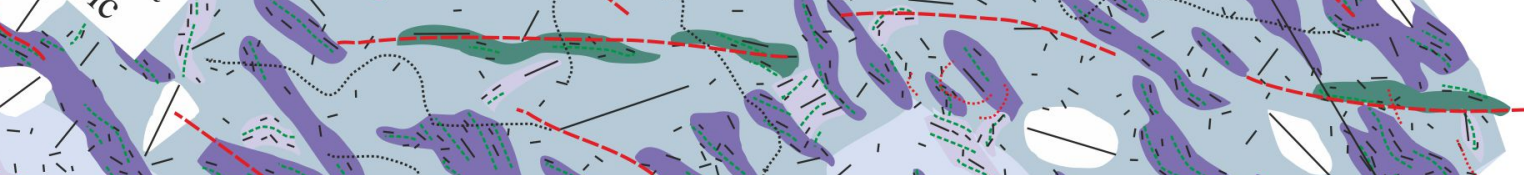
anc

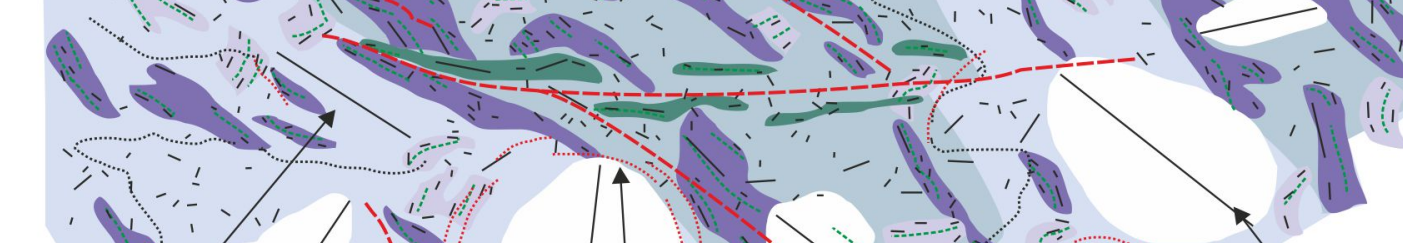

arcuate geometry

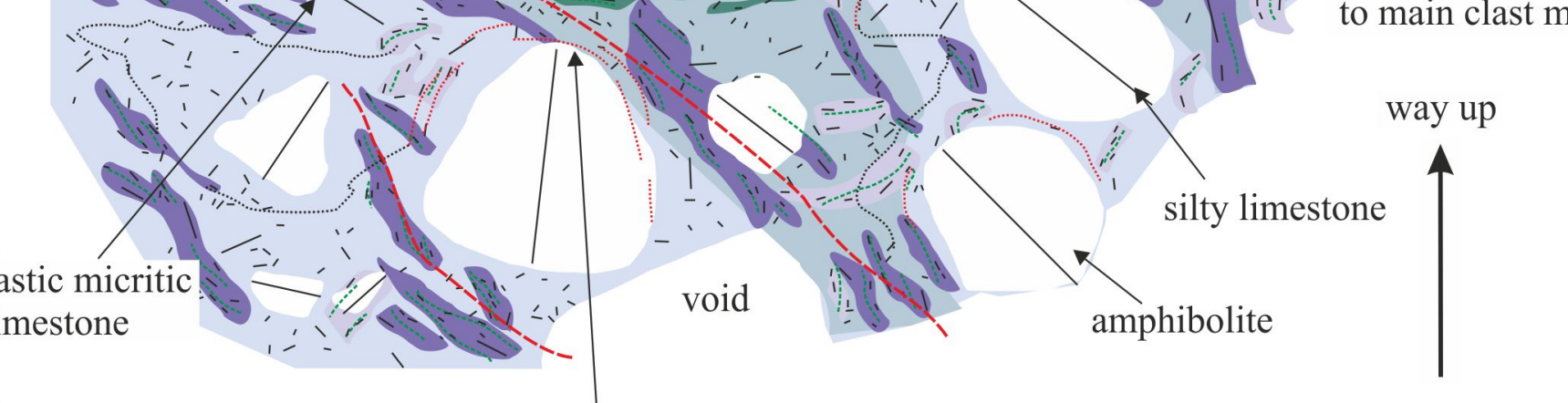
limestone

arcuate grain alignments

$10 \mathrm{~mm}$
around large clast

Top

clay-rich laminae

$\square$ diamicton

$\square$ laminated calcareous silt and clay

Microfabric domains

$\square$ crenulated (S1) fabric

$\square$ moderately inclined (S2) fabric

$\square$ apparently late (S3) fabric

…….... bedding/layering

_....... fold axes

_...- thrust

........... grain alignments

clast microfabric

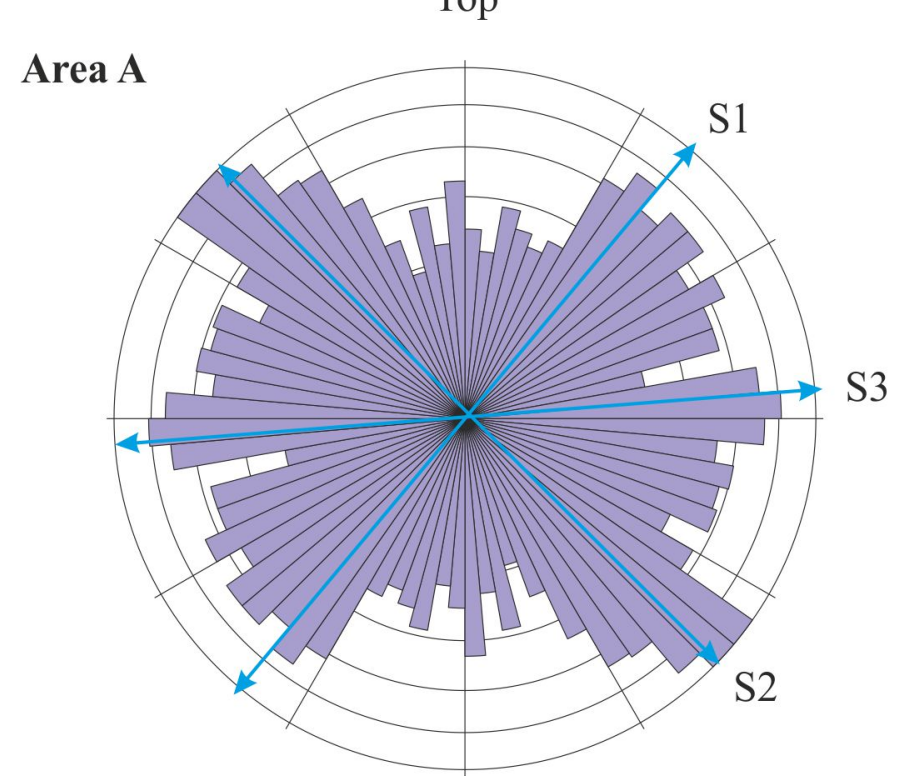

$\mathrm{N}=937$

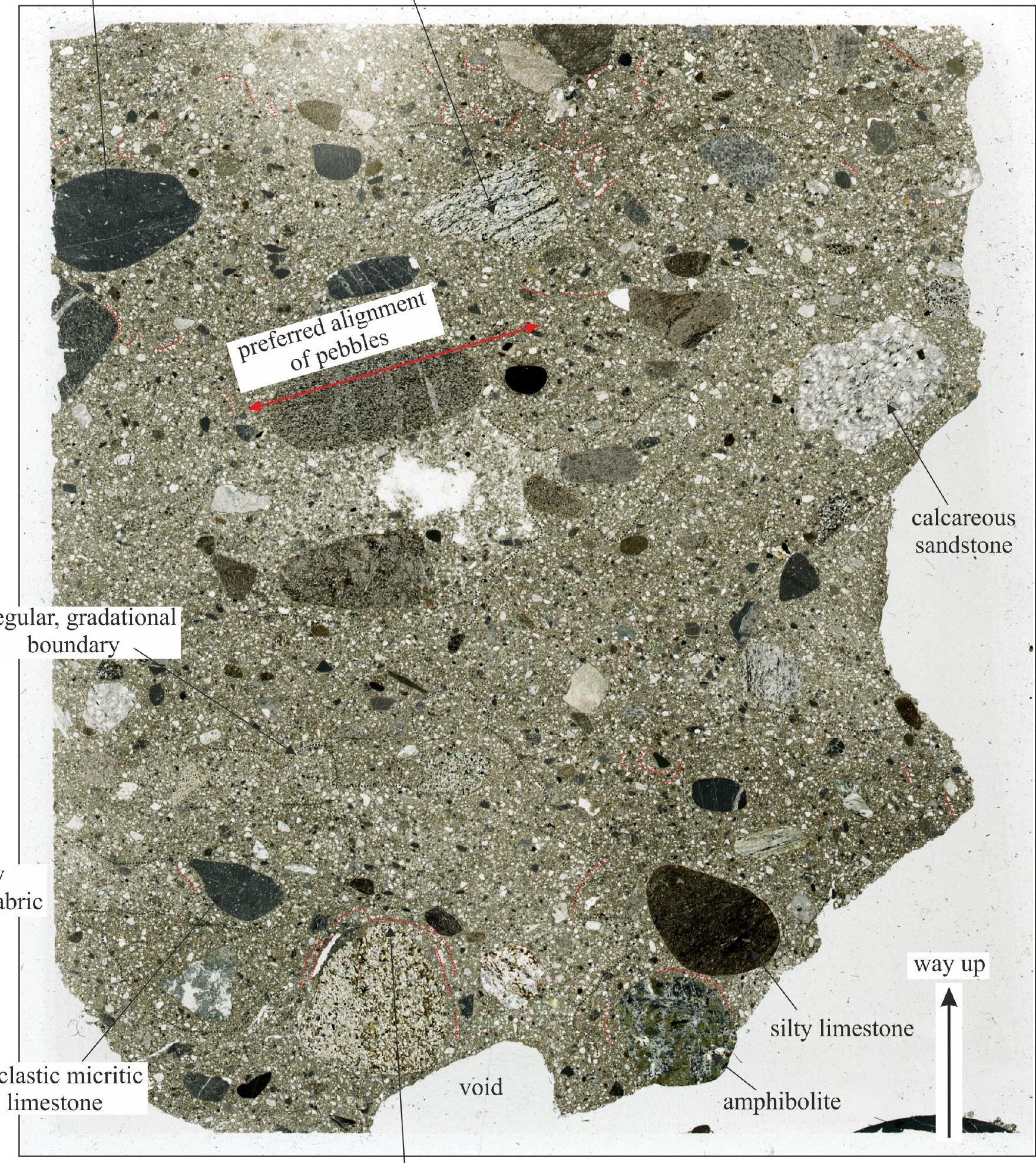

Sample R.165 arcuate grain alignments

around large clast
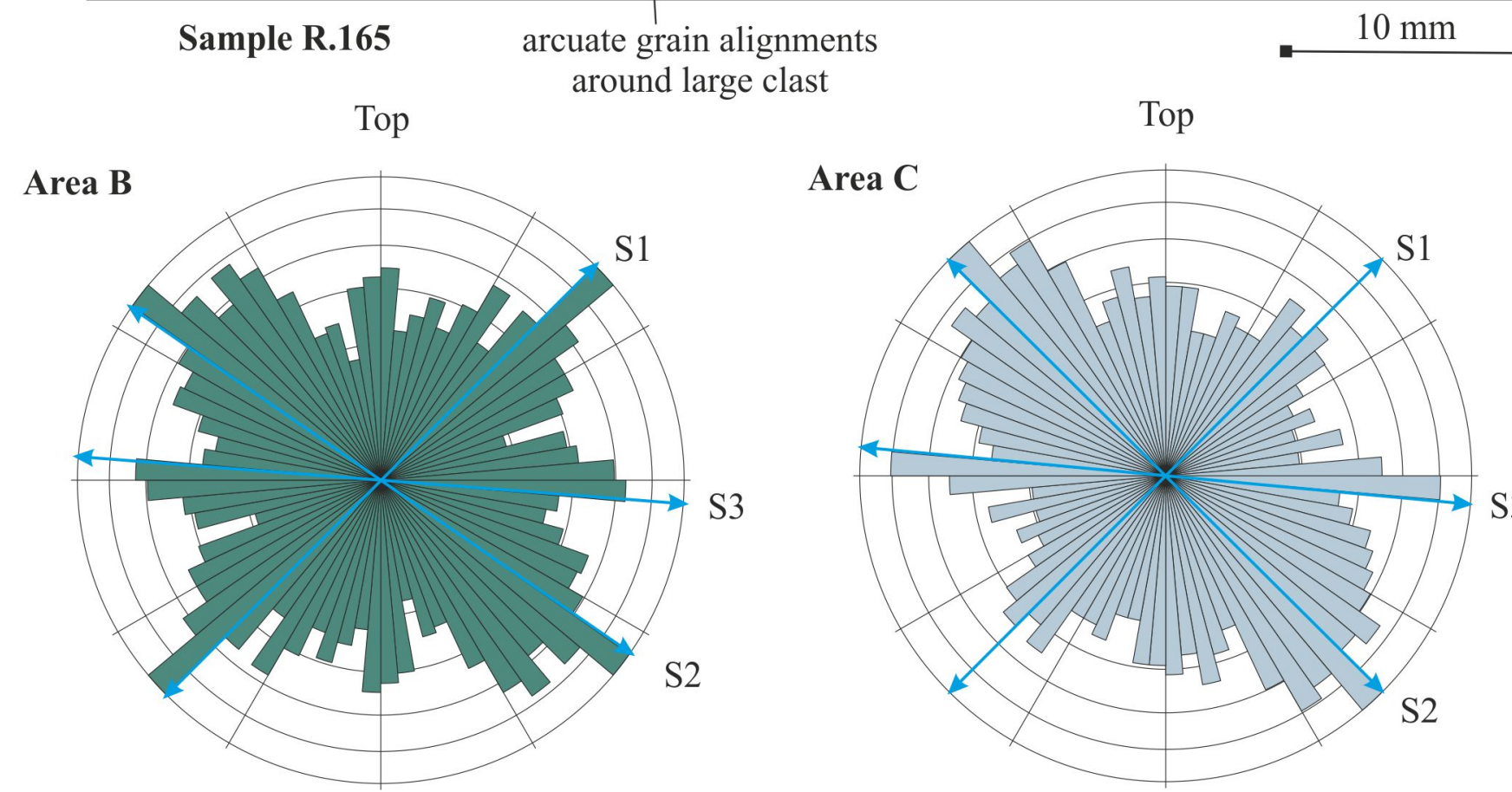

$\mathrm{N}=843$

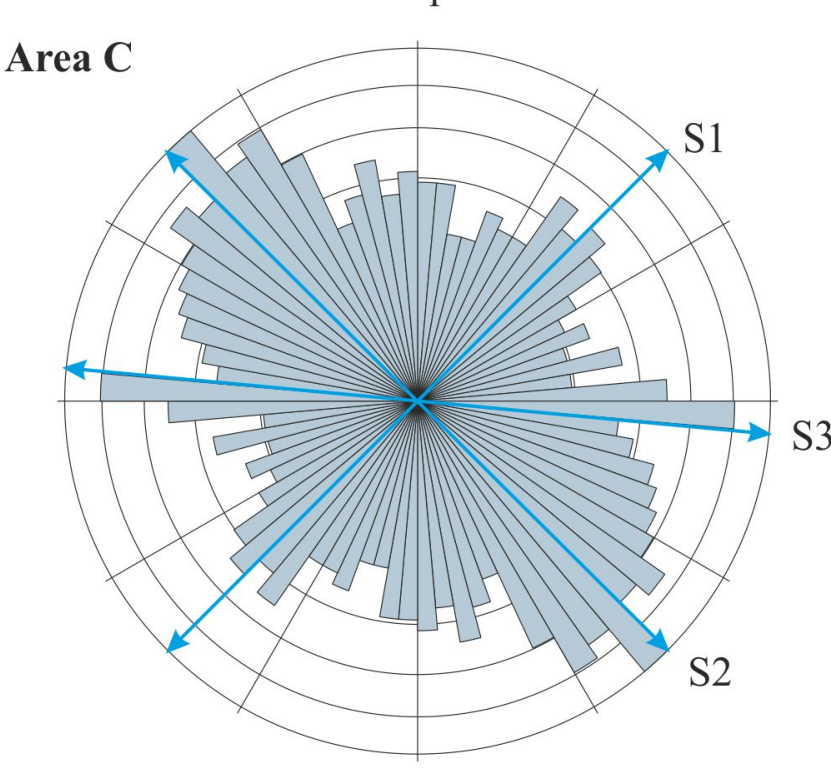

$\mathrm{N}=830$ 


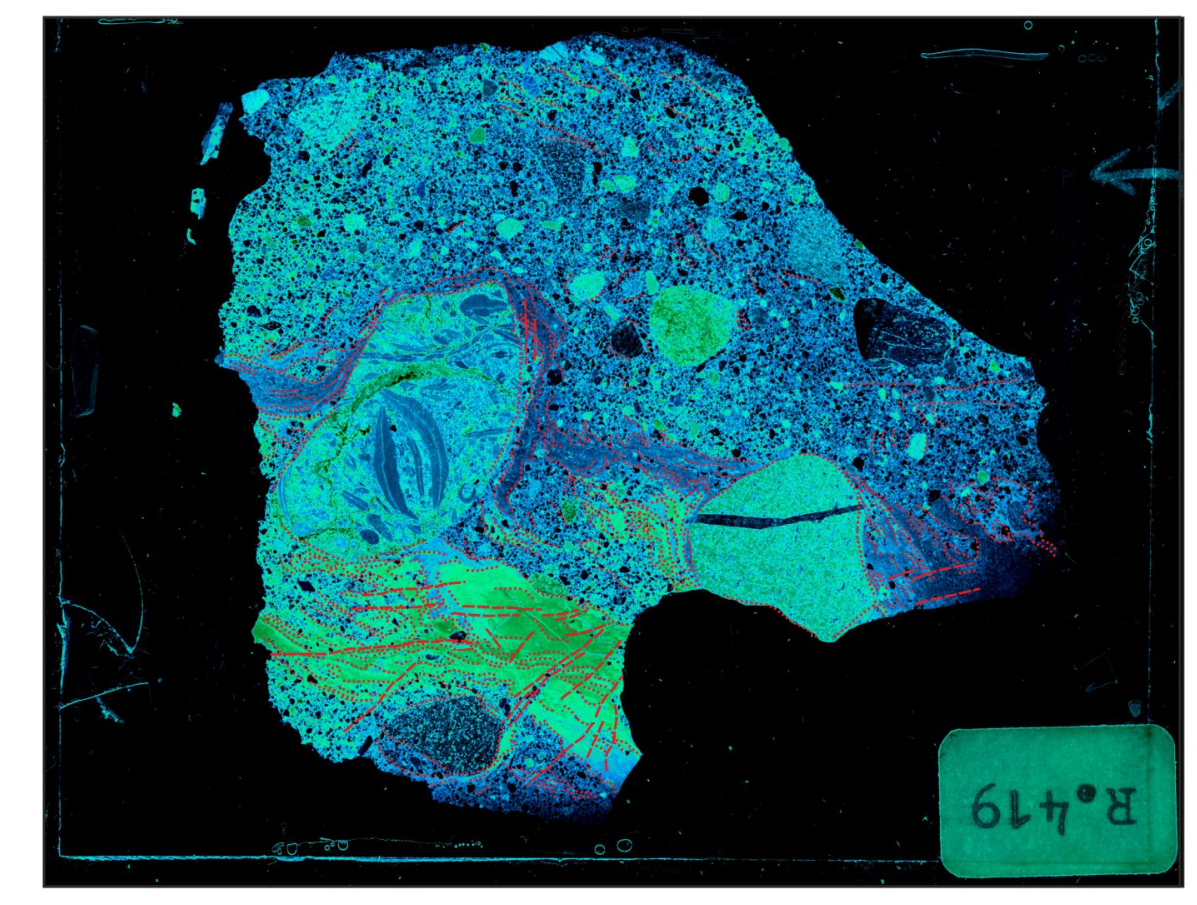

false colour image
Lithology
$\square$ sandy diamicton
$\square$ clay-rich diamicton
$\square$ laminated calcareous silt and clay
Microfabric domains
$\square$ crenulated (S1) fabric
$\square$ moderately inclined (S2) fabric
$\square$ apparently late (S3) fabric

\section{Top}

All data

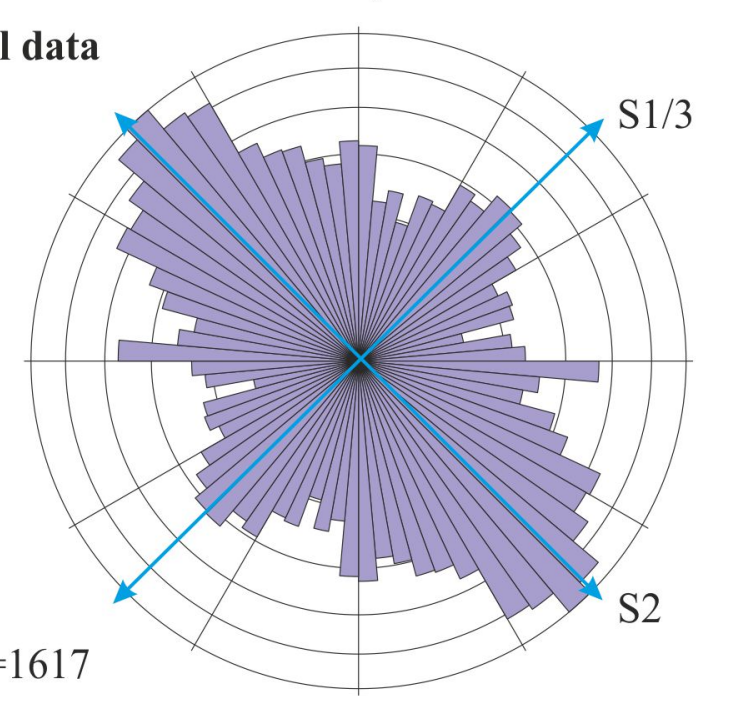

$\mathrm{N}=1617$

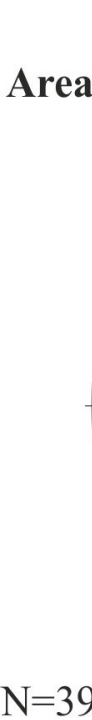

$$
\begin{aligned}
& \text { …...... bedding/layering } \\
& \text { ….... fold axes } \\
& \text {-...- thrust } \\
& \text {............ grain alignments } \\
& \text { c...-. clast microfabric }
\end{aligned}
$$

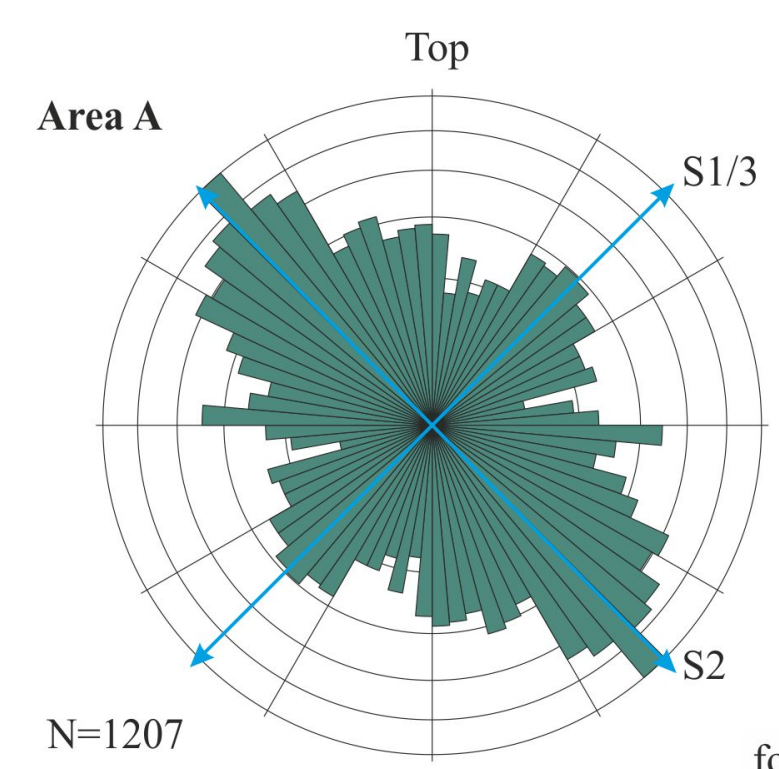

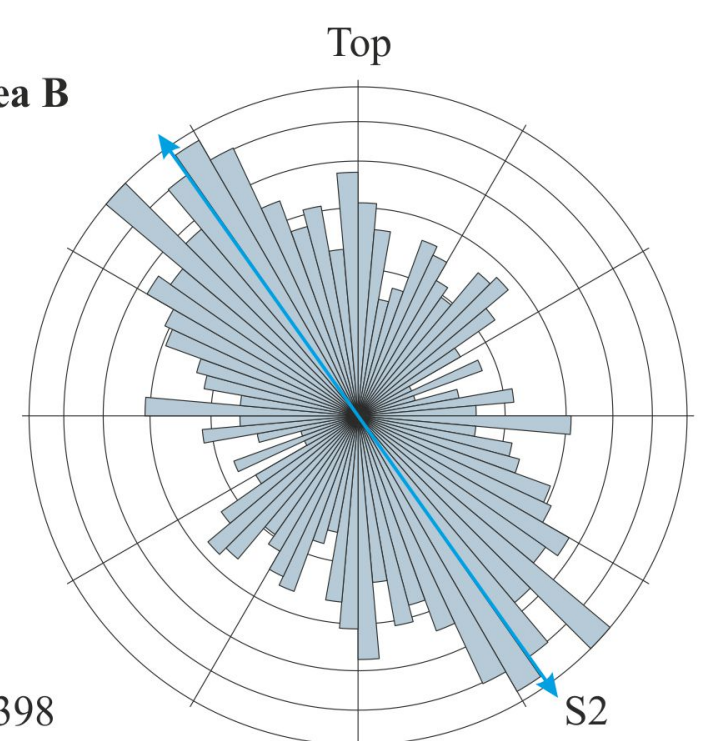

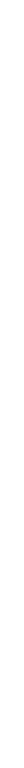

folding associated with
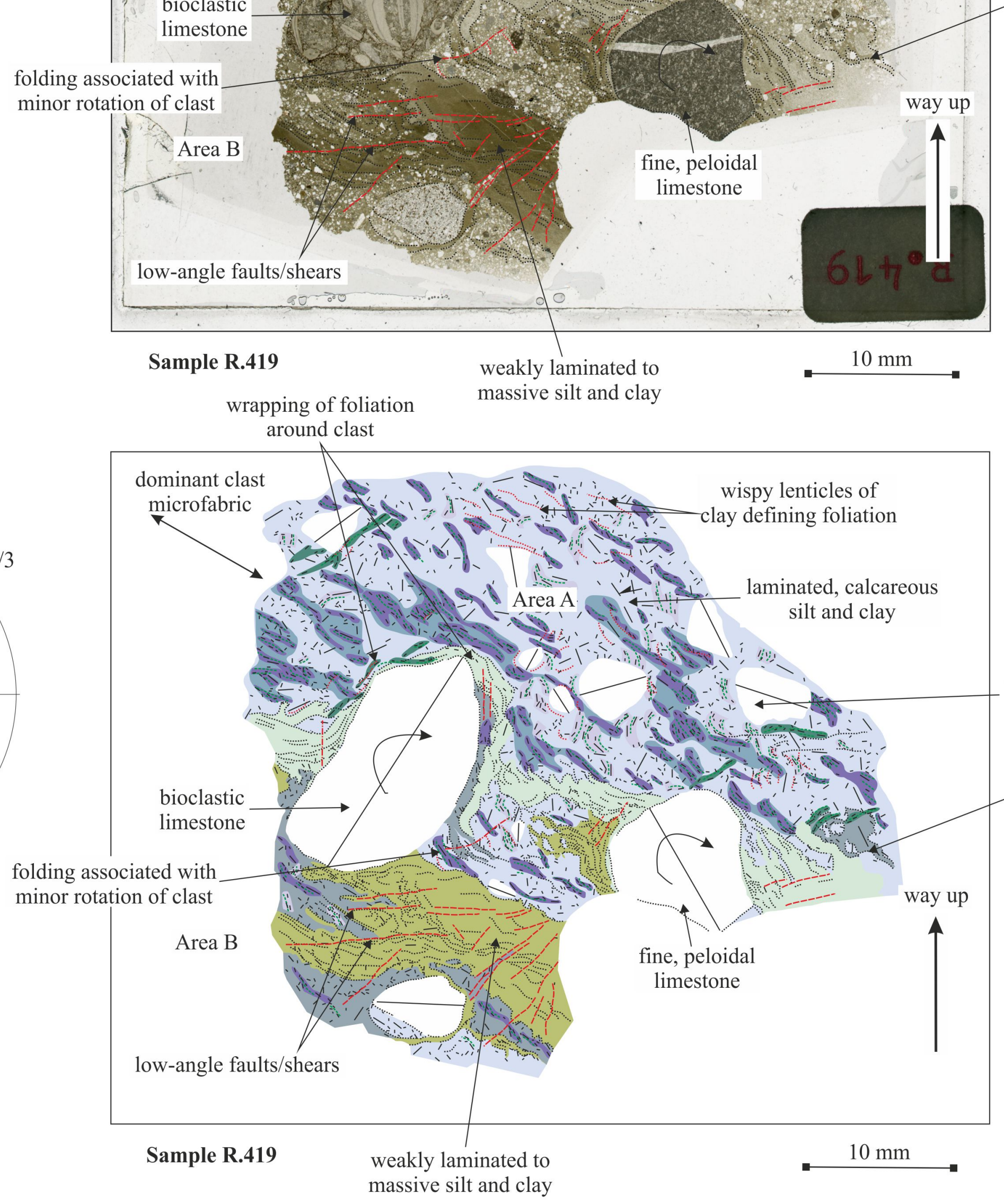

quartzofeldspathic metamorphic rock

highly irregular flame-like boundary

quartzofeldspathic metamorphic rock

highly irregular flame-like boundary 


\section{NW $\quad$ strong masepic plasmic fabric parallel to bedding}

clay cutan fillted water-escap conduits developed alon bedding surfaces

SE
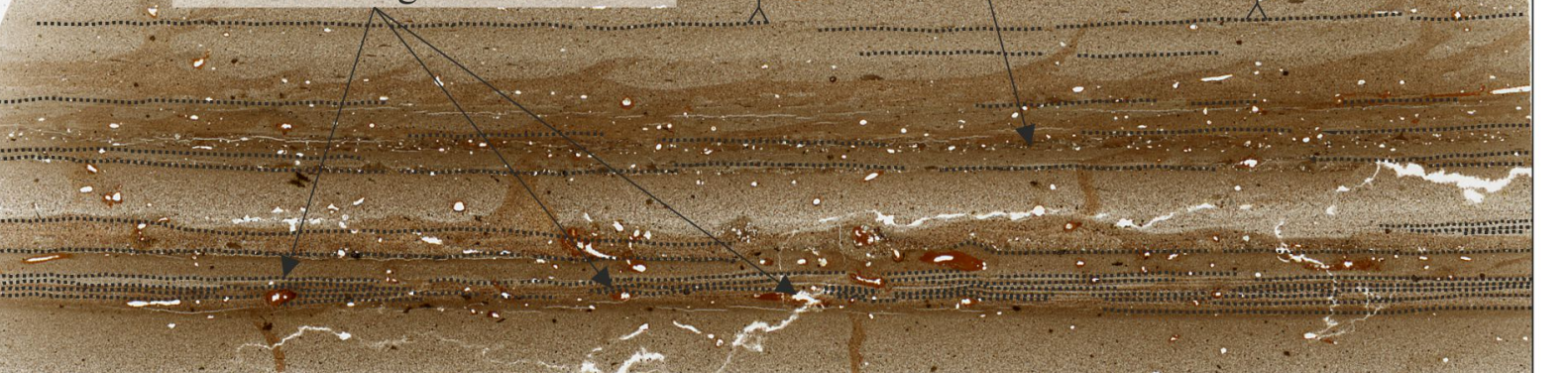

horizontal lamination,

normal grading

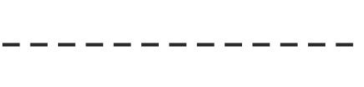

low-angle cross-lamination in fine sand-silt
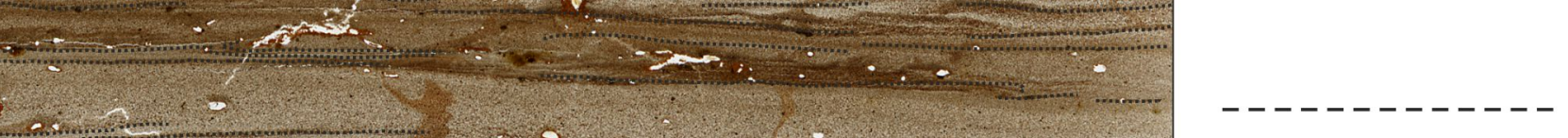

\section{-}

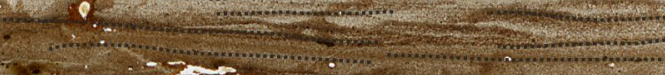

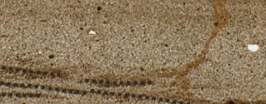

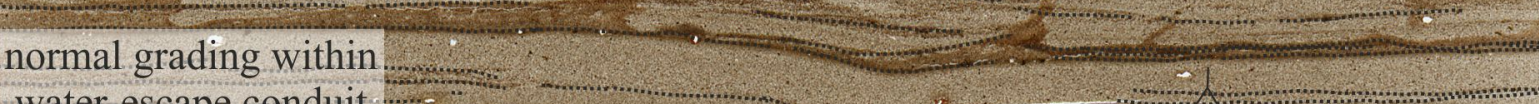
water-escape within water-escape conduit $\div \div \div$

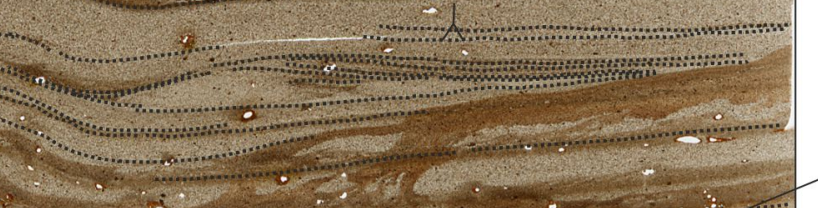

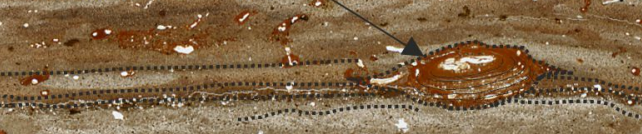

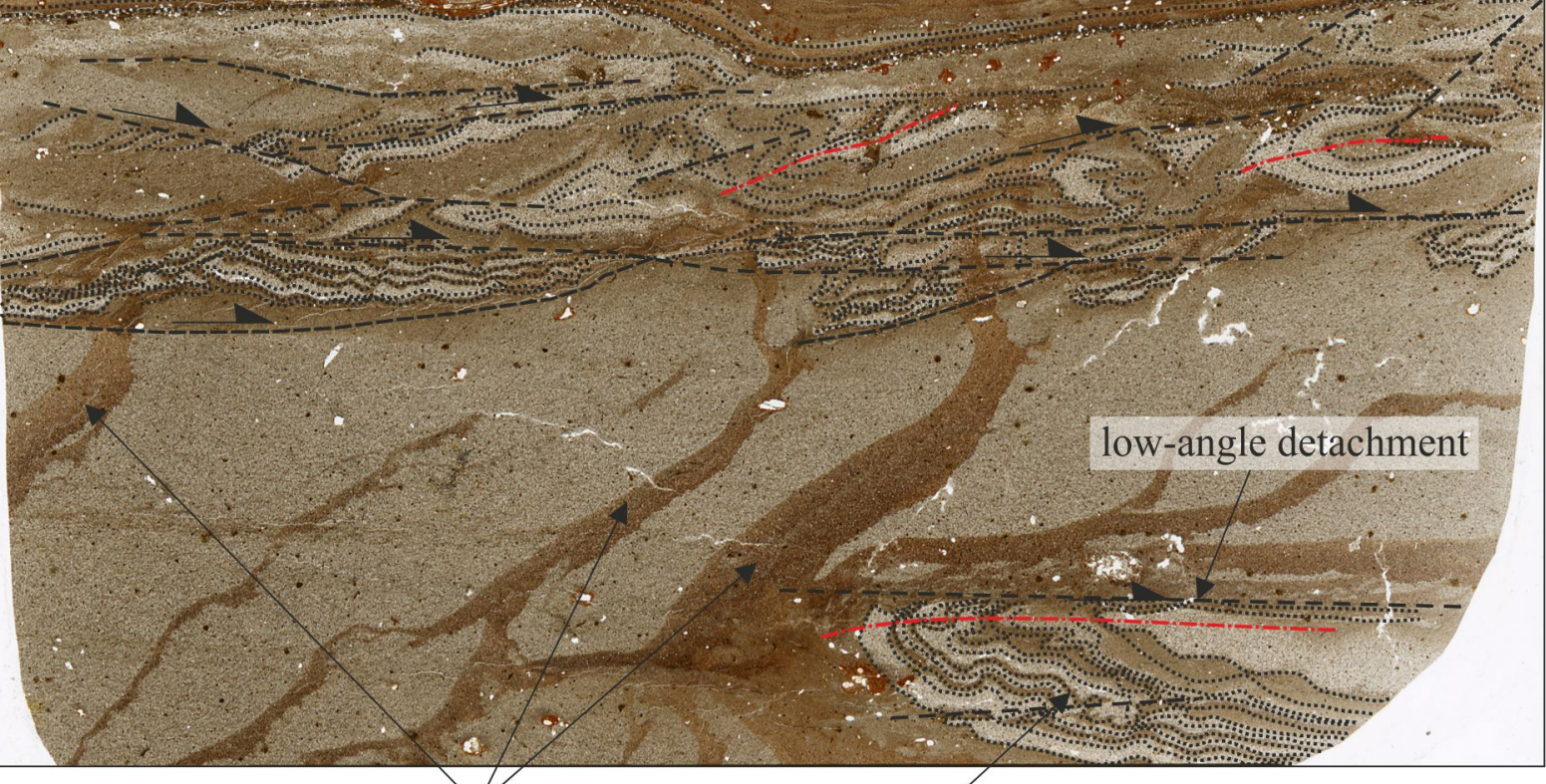

Sample N2840 $\quad \mathrm{Fe}_{2} \mathrm{O}_{3}$ staining (post-depositional)

recumbent fold $10 \mathrm{~mm}$

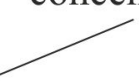

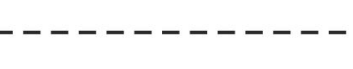

zone of recumbent folding, crenulation, and thrusting

------------
WW sand-grade dropstones

fold closure
fold recumben

SE

laminated fine silt and clay

with coarse silt interbeds

$-----------$

massive silt, partly with clay cement, top part deformed

laminated coarse silt and fine sand with thin clay laminae

fine silt and clay

laminated coarse silt and fine sand sand and coarse silt grains
concentrated in a few laminae

clay cutan filled clay cutan filled
water-escape conduits
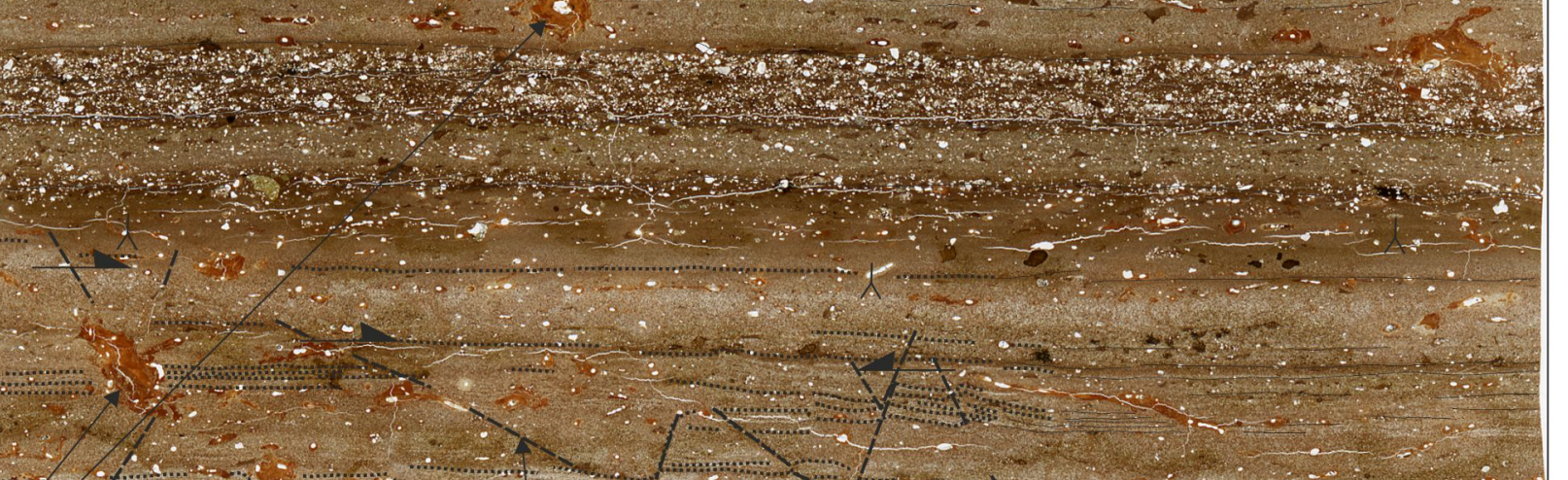

laminated fine silt and clay,

well-developed faults,

unistrial and masepic

plasmic fabric

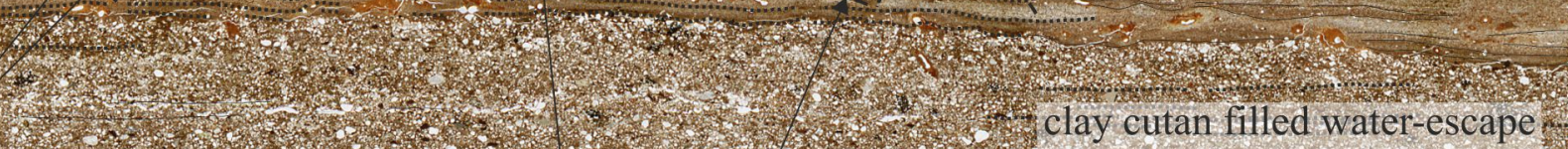

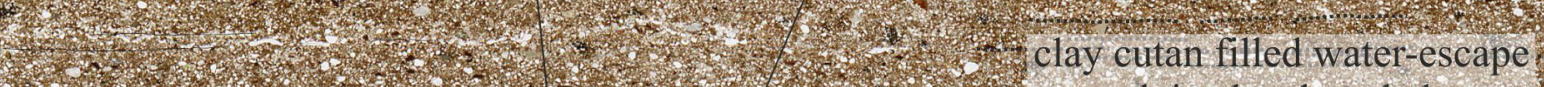

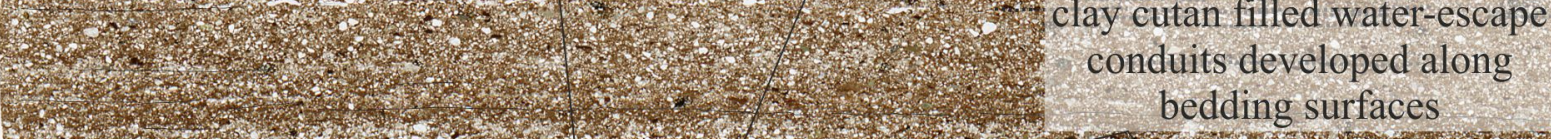

(2) bedding surfaces

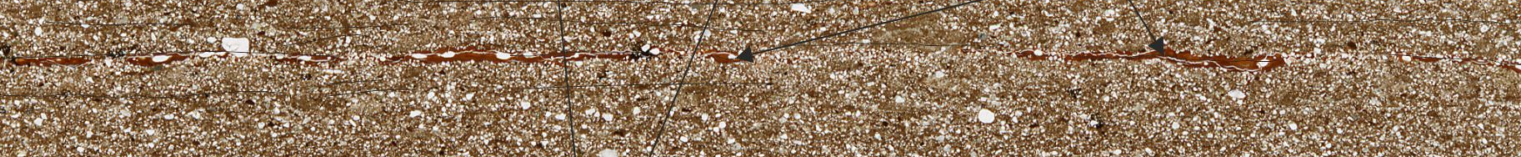

$-\ldots-n-\ldots-n$

laminated coarse silt and fine sand,

with thin clay laminae (disrupted), distinctive masepic plasmic fabric

parallel to bedding 


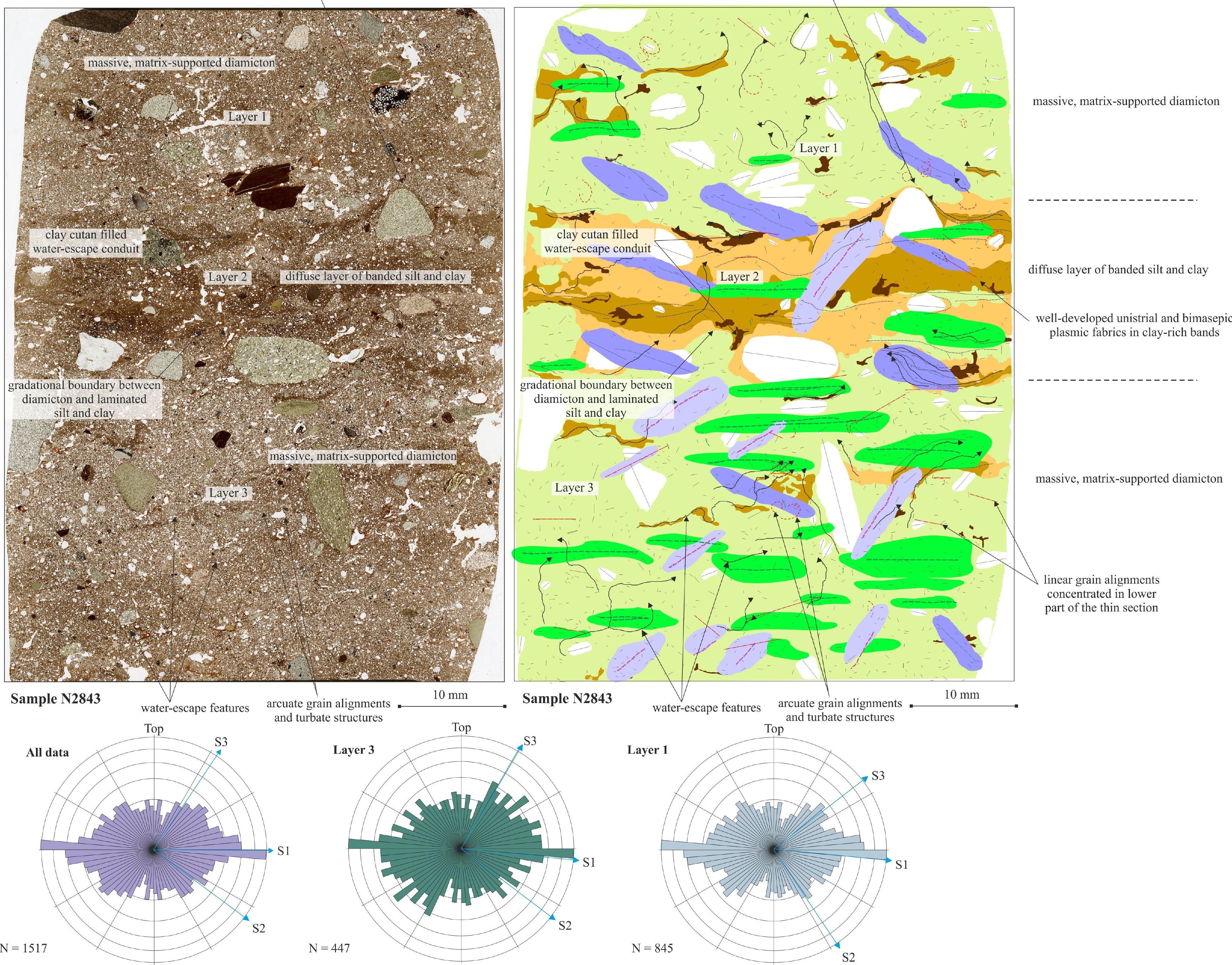




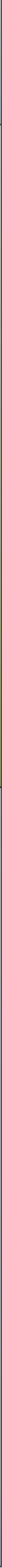




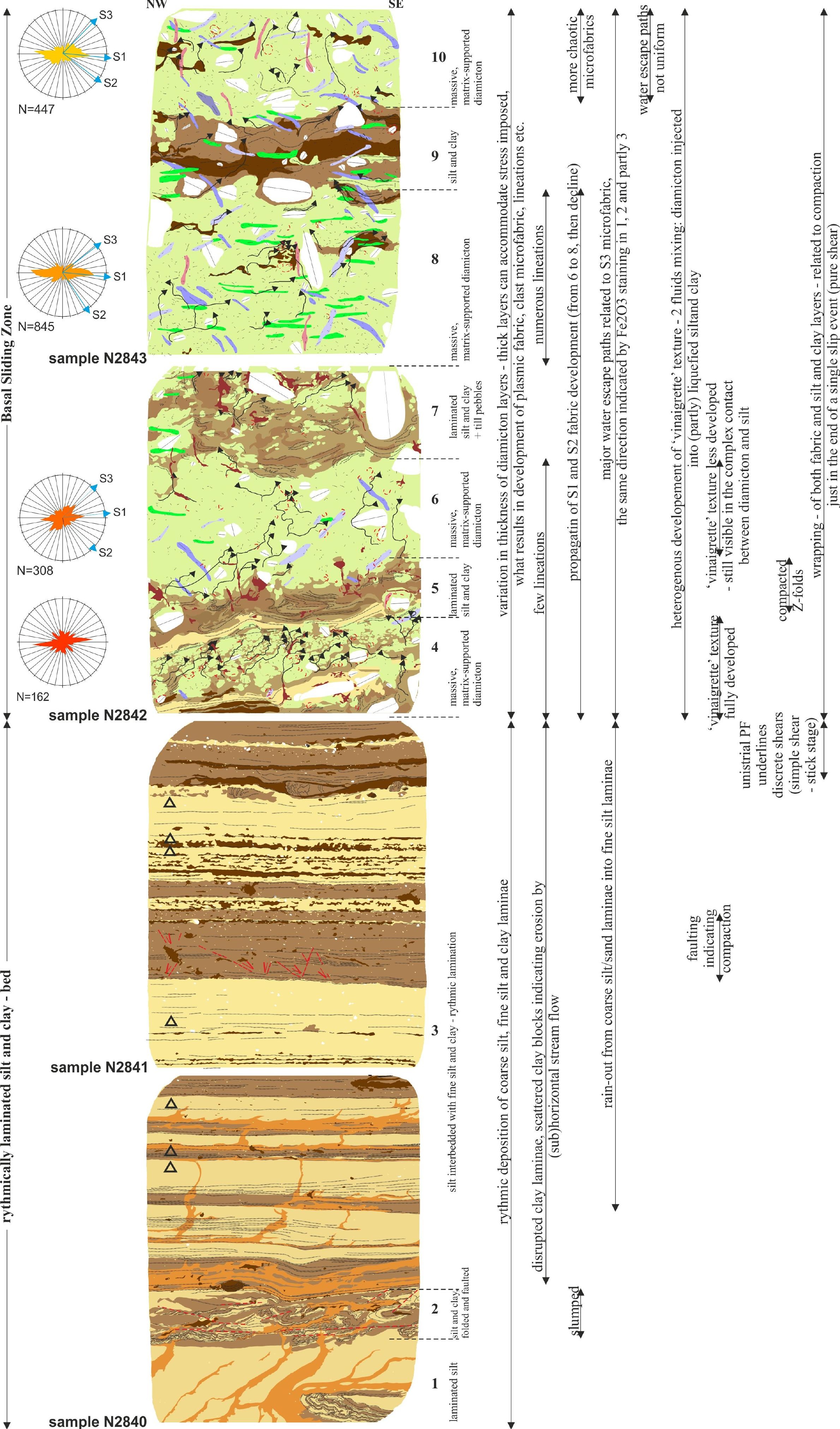



shear strain curve for the gravelly Batestown till from Thomason \& Iverson (2006)
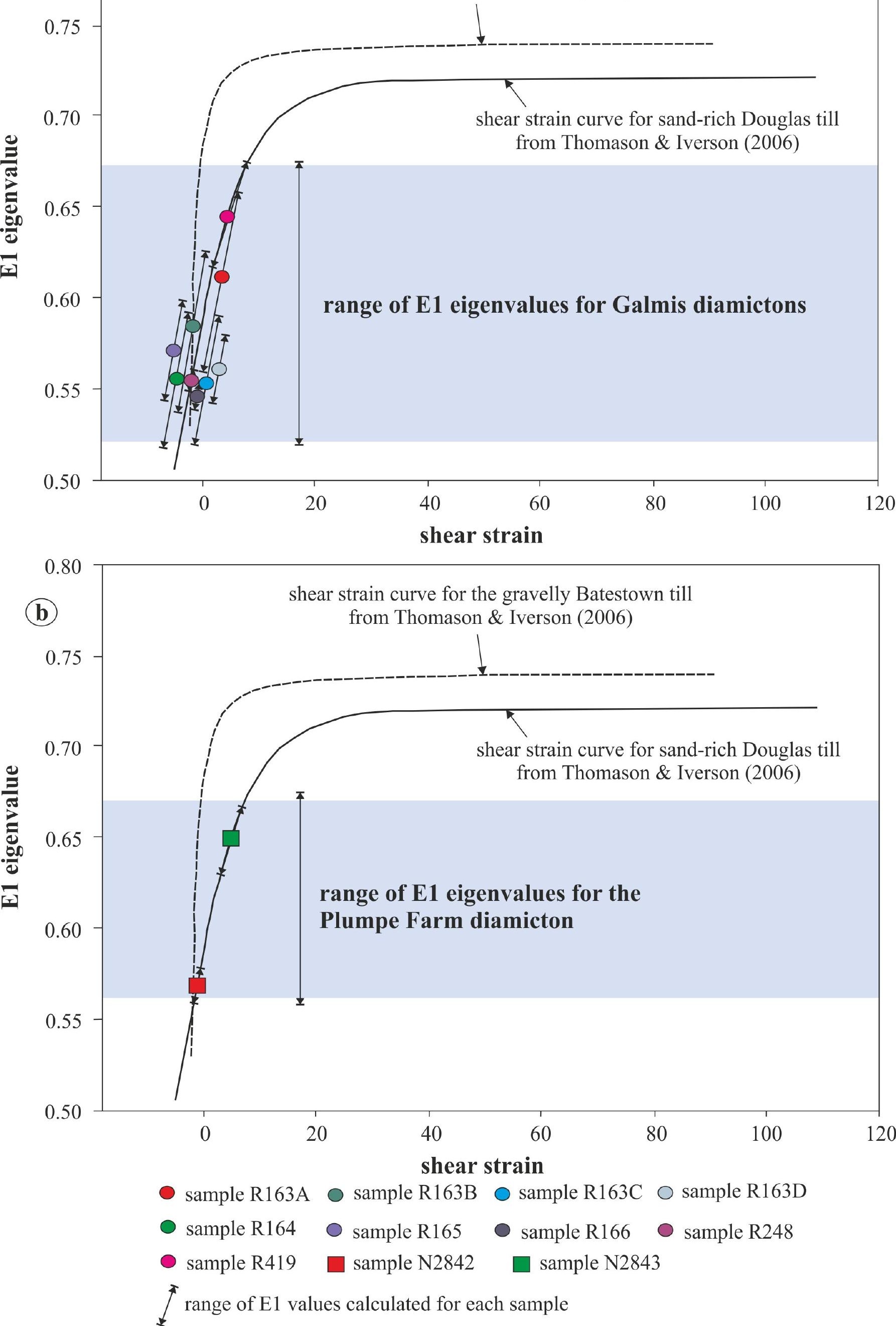